\title{
New Neotropical genera and species of the tribe Osoriini (Coleoptera: Staphylinidae: Osoriinae)
}

\author{
With 19 figures
}

ULRICH IRMLER ${ }^{1}$

${ }^{1}$ Institut für Ökosystemforschung, Abteilung Angewandte Ökologie, Universität, Olshausenstrasse 40, 24098 Kiel, Germany. uirmler@ecology.uni-kiel.de

Published on 2015-06-30

\section{Summary}

The paper is part of a comprehensive review of the Neotropical genera and species of the tribe Osoriini. Here, the remaining genera and species are described and a key to the Neotropical genera of the tribe is given. The following new genera are described: Osoriosetus with the new species O. hanagarthi, Neorhabdopsis with the new species N. brasiliensis, N. lutzi, N. panamae, and N. pecki. The following genera are new for the Neotropical region: Tumboecus FAGEL, 1959 with the new species T. verhaaghi and T. struyvei, Neosorius FAGEL, 1959 with the new species N. mexicanus and N. brasiliensis, Paratorchus MCColl, 1985 with the eight species P. tilli spec. nov., P. brasiliensis (IRMLER, 1983 ) comb. nov., P. boliviensis (Irmler, 2005) comb. nov., P. breviatus (Irmler, 2007) comb. nov., P. chilensis (IrMLER, 2005) comb. nov., P. chiriquensis (Irmler, 2005) comb. nov., P. columbiensis (Irmler, 2005) comb. nov., P. panamae (Irmler, 2005) comb. nov., Holotrochopsis Fagel, 1955 with the six species H. pubescens (Sharp, 1876) comb. nov., H. subtilis (ShARP, 1876) comb. nov., H. amazonicus (Irmler, 1981) comb. nov., H. adisi (IrMLER, 2013) comb. nov., H. danoffburgi (Irmler, 2001) comb. nov., H. siolii (Irmler, 2001) comb. nov. New species are added to the genus Oryssoma Notman, 1925 O. polita spec. nov., O. exalatum (Blackwelder, 1943) comb. nov., and O. microptera (BLACKWELDER, 1943) comb. nov.

\section{Key words}

Neotropics, new species, new genera, Osoriini, Staphylinidae

\section{Zusammenfassung}

Die vorliegende Arbeit ist Teil eines umfangreichen Reviews über die neotropischen Gattungen und Arten des Tribus Osoriini. Neue oder bisher nicht aus der Neotropis aufgeführte Gattungen und Arten werden beschrieben und ein Bestimmungsschlüssel der neotropischen Gattungen vorgestellt. Die folgenden neuen Gattungen werden beschrieben: Osoriosetus mit der neuen Art O. hanagarthi, Neorhapdopsis mit den Arten N. brasiliensis, N. lutzi, N. panamae und N. pecki. Die fogenden Gattungen sind neu für die Neotropis: Tumboecus Fagel, 1959 mit den neuen Arten T. verhagghi und T. struyvei, Neosorius FAgel, 1959 mit den neuen Arten N. mexicanus und N. brasiliensis, Paratorchus McColl, 1985 mit den acht Arten P. tilli spec. nov., P. brasiliensis (Irmler, 1983) comb. nov., P. boliviensis (Irmler, 2005) comb. nov., P. breviatus (Irmler, 2007) comb. nov., P. chilensis (Irmler, 2005) comb. nov., P. chiriquensis (Irmler, 2005) comb. nov., P. columbiensis (IrMler, 2005) comb. nov., P. panamae (Irmler, 2005) comb. nov., Holotrochopsis Fagel, 1955 mit den sechs Arten H. pubescens (Sharp, 1876) comb. nov., H. subtilis 
(Sharp, 1876) comb. nov., H. amazonicus (Irmler, 1981) comb. nov., H. adisi (Irmler, 2013) comb. nov., H. danoffburgi (Irmler, 2001) comb. nov. und H. siolii (Irmler, 2001) comb. nov. Folgende Arten werden für die Gattung Oryssoma Notman, 1925 neu beschrieben bzw. zugeordnet: O. polita spec. nov., O. exalatum (BlaCKWELDER, 1943) comb. nov. und O. microptera (BLACKWELDER, 1943) comb. nov.

\section{Schlüsselwörter}

Neotropis, neue Arten, neue Gattungen, Osoriini, Staphylinidae

\section{Introduction}

The present study is part of a more comprehensive study on the Neotropical Osorius complex. According to FAgel (1959) the genera of the Osorius complex in the tribe Osoriini are characterised by the following characters: at least slightly enlarged protibia with spines on its outer edge, and geniculate antennae. The species formerly described in the genus Osorius were reviewed, new species and genera described (IRMLER 2010b, IRMLER 2014a). Subsequently, the genus Osoriellus FAGEL, 1959 was studied that represents the most species rich genus in the Neotropics (Irmler 2014b). The genus Osoriellus comprises all species with setose posterior face of the protibia. Many species formerly described under the genus Osorius were transferred to the genus Osoriellus. During the present study several species were found that could not be included into genera known from the Neotropical region. New genera have to be established and new species described and placed to genera either known or new to the Neotropics. Additionally, a review of the Neotropical species of the genus Holotrochus was executed and compared with the African genera Holotropsis FAGEL, 1955, Holotrochomorphus FAgEL, 1955 and the New Zealand genus Paratorchus McCoLL, 1985 that resulted in the presence of the genera Holotrochopsis FAGEL, 1955 and Paratorchus McColl, 1985 in the Neotropical fauna. Therefore, a new key to the genera of Osoriini including the newly described or newly found genera for the Neotropics is presented here.

\section{Material and methods}

The material studied in this investigation is presently deposited in the following museums and private collections.

AMNH American Museum of Natural History, New York, U.S.A.

BMNH The Natural History Museum, London, United Kingdom

KNHM University of Kansas, Museum of Natural History, Lawrence, Kansas, U.S.A.

MNHP Muséum national d'Histoire naturelle, Paris, France

NMPC National Museum of Natural History, Prague, Czech Republic

UIC Ulrich Irmler collection, Plön, Germany

TSC Tim Struyve collection, Mechelen, Belgium
For the photographs of the species, a Makroskop M 420 (Wild Herbrugg) was used in combination with a digital camera (Leica EC3). CombineZ5 (Hadley 2006) was used to optimise the depth of focus. Length was measured in the middle of tagmata: head from clypeus to posterior edge, pronotum from anterior to posterior edge along midline, elytra from anterior edge at shoulders to posterior edge; width at the widest part of tagmata (head width includes eyes). In the measurement of total length, the abdominal inter-segmental space is omitted.

\section{Results}

Description of the new genera and remarks to genera new to the Neotropics

\section{Holotrochopsis FAGEL, 1955}

The genus Holotrochopsis FAgEL, 1955 was described on the basis of some African species that are characterised by distinct pubescence and large prominent eyes. FAGEL (1955) separated the genus from the related genus Holotrochomorphus FAGEL, 1955 mainly by the larger eyes. In contrast to Holotrochopsis FAGEL, 1955, eyes in Holotrochomorphus FAGEL, 1955 are smaller and not prominent. Additionally, both genera differ in the hairline of the pubescence. In Holotrochopsis FAGEL, 1955 the hairline is straight, from front to back, whereas it is transversal in Holotrochomorphus FAgEL, 1955q.

The referring species of the Neotropics were described under the $H$. pubescens group of the genus Holotrochus ERICHSON, 1840 and are transferred here to Holotrochopsis FAGEL, 1955.

\section{Neorhapdopsis gen. nov.}

Type species: Neorhabdopsis lutzei spec. nov.; here designated as the type species for the genus.

Etymology: The generic name is a combination of the Greece word Neo meaning new and Rhabdopsis that refers to the similar African genus. 
Description: Length \& habitus: elongate; blind with reduced elytra and long abdomen; small species of about $1.5-2.0 \mathrm{~mm}$.

Head approximately quadrate; clypeus semicircular; sinuate in front of base of antennae; labrum rectangular; eyes absent; setiferous punctation; without distinct neck.

Antennae not geniculate; first antennomere thick; width of antennomeres increasing from second antennomere to apex.

Pronotum quadrate or slightly longer than wide; widest in middle or close to anterior angles; in posterior half convergent; lateral margin fine; with setiferous punctation.

Elytra transverse; shorter than pronotum; divergent from shoulders to posterior edge; hind wings reduced; with suture and suture lines; with setiferous punctation.

Abdomen densely and coarsely punctate; punctures with long setae.

Protibia enlarged; inner edge emarginated, with comb; in posterior aspect, totally visible; outer edge with spines inserted directly on edge; posterior face with few long setae; tarsi pentamere.

Aedeagus with spiral endophallus; apical lobe curved; paramera present; with one or two long setae at apex.

Diagnosis: Similar to the African genus Rhapdospsis FAGEL, 1959 in the yellow colouration, shape of pronotum, short elytra and absence of eyes. However, the aedeagus of these two genera is different: the aedeagus of Rhapdospis has no parameres and is nearly gobular, whereas the aedeagus of Neorhapdopsis has distinctive parameres with one or two apical long setae.

\section{Neosorius FAGEL, 1959}

The genus Neosorius was defined by FageL (1959) using the following characters: protibia at least shortly dentate; posterior face of protibia at least with few spines; aedeagus with endophallus. The problems with the genera Neosorius and Osoriellus Fagel (1959) were already discussed in the papers concerning the genera Osorius (Irmler 2010b) and Osoriellus (Irmler 2014b). Many species in the Neotropics have a digitate protibia but only setose posterior face of the protibia and no endophallus. They are now placed in the genus Osoriellus. Finally, only two new species remained that could be placed to the genus Neosorius since they combine all characters of the genus.

\section{Osoriocanthus FAgEL, 1959}

The genus Osoriocanthus was defined by Fagel (1959) using the following characters: dentate shoulders of elytra; long setae on posterior face of the protibia; digitate protibia; no endophallus. No species was found combining all characters of the genus. A few species newly described under the genus Osoriellus are very similar (IRMLER 2014b), but differ in some respect. Only one female specimen from Peru might be placed to the genus since it combines all generic characters. However, as the male is unknown, the aedeagus could not be studied. Nevertheless, it might be that the genus exists in the Neotropical region

\section{Osoriosetus gen. nov.}

Type species: Osoriosetus hanagarthi spec. nov., here designated as the type species for the genus.

Etymology: The generic name is a combination of the words Osorius that refers to the relation to the Osorius complex and setus referring to the densely setose posterior face of the protibia.

Description: Length \& habitus: elongate; typical habitus of genera of Osorius complex; moderately large species of about 5 to $6 \mathrm{~mm}$.

Head approximately quadrate; sides in front of eyes sinuate; labrum rectangular; eyes well developed; setiferous punctation; setae short; few longer supraocular and praeocular setae; without distinct neck; neck separated from vertex by absence of punctation.

Antennae geniculate; antennomeres increasing in width from base to apex.

Pronotum subparallel; emarginate in front of posterior angles; lateral margin fine, of equal width throughout its total length; setiferous punctation coarse.

Elytra approximately quadrate; shoulders nearly rectangular; suture present; setiferous punctation in irregular rows.

Abdomen with all tergites densely and coarsely punctate; punctures setiferous.

Protibia extremely enlarged; semicircular, posterior face setose; without spines; outer edge of protibia with more than 10 spines; in posterior aspect, comb and emargination of inner edge completely covered; in posterior aspect without inner emargination; inner edge straight. Aedeagus without endophallus; apical lobe curved; paramera absent.

Diagnosis: The genus is closely related to the genera Antillosorius Irmler, 2010b and Osoriellus Fagel, 1959 concerning the setose posterior face and the absence of spines on the posterior face of the protibia. As in Osoriellus, the lateral margin of the pronotum is equal in width, which separates Osoriosetus and Osoriellus from Antillosorius. The specific semicircular shape of the protibia is unique in the genera of the Osorius complex and justifies establishing a new genus. At present, the genus is only known from South-America. 


\section{Paratorchus McCoLL, 1985}

The referring species from New Zealand were described under the generic name Paratrochus McColl, 1982. As Paratrochus was preoccupied, McColl (1985) later renamed the genus to Paratorchus McColl, 1985. However, the definition of the genus was vague and a comparison with Holotrochus or related genera was not made. McColl (1982) defined Paratorchus by reduced eyes with one to ten omatidia and reduced elytra that are shorter than the pronotum and much wider than long. Furthermore, sutural striae are sometimes absent, shoulders prominent, and abdominal pubescence variable.

FAGEL (1955) described two African genera that are also characterised by absence of sutural striae, i.e. Holotrochoposis FAGEL, 1955 and Holotrochomorphus FAgEL, 1955. Both genera are additionally characterised by distinct pubescence. Some species of Holotrochomorphus FAGEL, 1955 have reduced elytra (FAGEL, 1958) but never as short as in Paratorchus McColl, 1985.

Similar species from the Neotropics were described under a specific group of the genus Holotrochus by IRMLER (1981, 1987, 2005), but included all species with reduced eyes independent of the elytral length. The recent finding of a new species from Mexico shows that species with reduced eyes and elytra and indistinct sutural striae are widely spread in the Neotropics and can be separated from Holotrochus not only by reduced eyes but also by the absence or reduction of the sutural striae.

Therefore, species with these characters will be transferred to Paratorchus McColl, 1985. Regarding the Neotropical species, Paratorchus is separated from Holotrochus by reduced eyes with one to twenty omatidae, reduced elytra that are much wider than long, absence or indistinct sutural striae, and rectangular or even dentate shoulders.

Species with reduced eyes but quadrate elytra such as H. neotropicus IRMLER, 1981 or with distinct sutural striae such as H. centralensis IRMLER, 2005 will remain in the genus Holotrochus.

\section{Tumboecus FAGEL, 1959}

The genus Tumboecus was created by FAgEL (1959) on the basis of one African female specimen. The African species, T. nitidus, is characterised by pentamere tarsi, non-geniculate antennae, protibia not enlarged, but with five long spines at its outer edge, normally long elytra and the presence of hind-wings. These characters are also found in the Neotropical species of the genus. In contrast to the African species with fine punctation, the Neotropical species are densely and coarsely punctate and punctures are setiferous. However, this difference does not justify creating a new genus. Unfortunately, the African specimen is a female. Thus, nothing is known about its aedeagal structure. The Neotropical species of the genus have an aedeagus that resembles that of the genera of the Osorius complex. It has no paramera and a specific endophallus, which resembles those of the genus Neosorius Fagel, 1959. A generic difference between the African and Neotropical species can be only established, if males of African species are found and the aedeagi differ considerably from the Neotropical species.

The species of the genus Tumboecus FAgEL, 1959 are between 2 and $3 \mathrm{~mm}$ long. They resemble small species of the genus Osoriellus FAgEL, 1959, but differ in the presence of an endophallus and the non-geniculate

\section{Key to the genera of the tribe Osoriini}

1. Protibia and mesotibia with setae at outer edge, antennae not angulate 2

At least protibia with several spines on outer edge, antennae mostly angulate …................................................. 8

2. Pronotum in front of posterior edge deeply emarginate ...................................................................................... 3

Pronotum in front of posterior edge not emarginate

3. Eyes small, only few omatidia present, elytra short, twice as wide as long Mimotrochus IRMLER, 1987

Eyes of normal size, usually distinctly prominent, elytra longer, as wide as or longer than wide 4

4. Pronotum laterally margined including the emargination in front of posterior angles, posterior angles with depression Mimogonus FaUvel, 1903

Emargination of pronotum not margined Mimogonia CoIffait, 1978

5. Clypeus emarginate; head and pronotum with broad lateral margin Craspedus BERNHAUER, 1908 Clypeus not emarginate; head not margined, pronotum with a fine lateral margin

6. Elytra with sutural striae Holotrochus ERICHSON, 1839

Elytra without sutural striae or only remains of striae

7. Body pubescent, eyes normally large and prominent, elytra longer than wide Holotrochopsis FAGEL, 1955 
Body not pubescent, eyes short, not prominent, elytra short, much wider than long, habitus (Fig. 18A-F, 19A, B) Paratorchus McColL, 1985

8. Antennae angulate, first antennomere elongate, at least as long as three following antennomeres

Antennae not angulate, first antennomere thicker than following antennomere, but shorter than three following antennomere

9. Without eyes

With eyes, tarsi pentamere, habitus (Fig. 15E, F)

Tumboecus FageL, 1959

10. Tarsi with five tarsomeres, habitus (Fig. 16A-D)

Neorhabdopsis gen. nov.

Tarsi with three tarsomeres, habitus (Fig. 17B) Tavakilianidia Orousset, 1985

11. Tarsi with 3 tarsomeres

Tarsi with 5 tarsomeres

12 Eyes with one omatidium, habitus (Fig. 15A)

Ouloglene Notman, 1925

Eyes small or normally large, habitus (Fig. 15B, C, D)

Oryssoma Notman, 1925

13. Pronotum without lateral margin, clypeus with two long acute teeth, head and pronotum dull, body totally covered with setae Anancosorius Bernhauer, 1908

Pronotum with lateral margin, clypeal teeth, if present, broad or obtuse

14. Shoulders of elytra dentate

Osoriocanthus FAGEL, 1959

Shoulders of elytra not dentate

15. Protibia semicircular, comb of inner emargination not visible in posterior aspect, habitus (Fig. 17A)

Osoriosetus gen. nov.

Protibia broad, but never semicircular, comb of inner emargination at least partly visible in posterior aspect .... 16

16. Pronotum at least slightly emarginate in front of posterior angles, lateral margin of pronotum widened to posterior angles

- Margin of pronotum equal in width, sides evenly narrowed from anterior to posterior angles or with emargination in front of posterior angles

17. Posterior side of protibia with setae and spines

Osorius GuÉRIN-MÉneville, 1829

Posterior side of protibia only setose, without short and thick spines

Antillosorius Irmler, 2010b

18. Posterior side of protibia only setose, without thick spines, aedeagus without endophallus

Osoriellus FAGEL, 1959

Posterior side of protibia with spines and setae, aedeagus with endophallus, habitus (Fig. 16E, F)

Neosorius FageL, 1959

antennae. Referring to the aedeagal structure and the non-geniculate antennae, Tumboecus seems to be intermediate between the genera of the Osorius complex and the other genera of the tribe Osoriini.

\section{Description of species \\ Neorhabdopsis brasiliensis spec. nov. \\ (Figs 5A-C, 16A)}

Type material: Holotype male: Brazil: Rio de Janeiro, Planalto Itatiaia $\left(44^{\circ} 33^{\prime} \mathrm{W}, 22^{\circ} 29^{\prime} \mathrm{S}\right), 2300 \mathrm{~m}$ elevation, 20.04.1958, leg. R. Arlé (UIC).
Etymology: The specific name derived from the country, where the species was collected.

Description: Length: $1.7 \mathrm{~mm}$, Colouration: Red, legs and antennae yellow.

Head: $0.26 \mathrm{~mm}$ long, $0.37 \mathrm{~mm}$ wide; clypeus semicircular; setiferous punctation moderately deep and dense; setae yellow; netlike microsculpture deep and dense; surface matt.

Antennae slightly longer than head and half of pronotum combined; first antennomere rectangular thick; second oblong, slightly less wide than first; third antennomere conical, slightly shorter and narrower than second; fourth antennomere as wide as third; approximately quadrate; following antennomeres slightly 
increasing in width; penultimate antennomere 1.5 times as wide as long.

Pronotum: $0.36 \mathrm{~mm}$ long, $0.40 \mathrm{~mm}$ wide; widest behind middle; slightly and evenly narrowed to anterior angles; to posterior angles narrowed in smooth convex curve; continuing to posterior margin without forming distinct angles; lateral margin extremely fine; not visible in dorsal aspect; setiferous punctation deep, coarse; on average, interstices between punctures half as wide as diameter of punctures; setae light yellow; moderately wide midline impunctate; netlike microsculpture deep and dense; surface matt.

Elytra: $0.26 \mathrm{~mm}$ long, $0.39 \mathrm{~mm}$ wide; widest in posterior third; with distinct shoulders; setiferous punctation still coarser than on pronotum; nearly coriaceous; setae light yellow; netlike microsculpture deep and dense; surface matt.

Abdomen with setiferous punctation still coarser than on elytra; on average, interstices between punctures one third as wide as diameter of punctures; without microsculpture; surface matt.

Protibia with few spines on outer edge and few long setae on posterior face.

Aedeagus with smoothly curved apical lobe; paramera slightly shorter than apical lobe and with long straight seta at apex; endophallus thick with elongate coil at lower and upper end and two narrow coils in between.

Diagnosis: Among the genus the species can be easily identified by the distinct microsculpture and the evenly curved sides of the pronotum.

\section{Neorhabdopsis pecki spec. nov.}

(Figs 6A-C, 16B)

Type material: Holotype male: Mexico, Veracruz, $1 \mathrm{mi}$. S Huatusco, $1344 \mathrm{~m}$ elevation, sampled by Berlese (\#171), 02.08.1969, leg. S. \& J. Peck (AMNH).

Etymology: The specific name is given to honor the collectors of the species.

Description: Length: $1.5 \mathrm{~mm}$. Colouration: yellow, legs and antennae light yellow.

Head: $0.22 \mathrm{~mm}$ long, $0.30 \mathrm{~mm}$ wide; clypeus semicircular; setiferous punctation irregularly deep and dense; setae short and yellow; on average, interstices between punctures shorter than diameter of punctures; on vertex partly as wide as diameter of punctures; netlike microsculpture wide and moderately deep; on average, meshes wider than diameter of punctures; surface slightly shiny.

Antennae slightly longer than head and half of pronotum combined; first antennomere thick and rectangular; second oblong and slightly narrower than first; third antennomere only half as wide as second and conical; following antennomeres wider than long and increasing in width; fourth slightly wider than long; sixth twice as wide as long; tenth 1.5 times wider than long.

Pronotum: $0.30 \mathrm{~mm}$ long, $0.31 \mathrm{~mm}$ wide; widest shortly behind anterior angles; smoothly and evenly narrowed to posterior angles; posterior angles obtuse, but distinct; lateral margin moderately fine; visible in dorsal aspect except near anterior angels; setiferous punctation coarse, partly coriaceous; setae short and yellow; moderately wide midline impunctate; on average, interstices between punctures distinctly shorter than diameter of punctures, but in posterior half interstices partly much wider; netlike microsculpture deep; on average, meshes as wide as diameter of punctures; surface moderately shiny.

Elytra: $0.19 \mathrm{~mm}$ long, $0.31 \mathrm{~mm}$ wide; widest in posterior half; shoulders smoothly curved, not rectangular; setiferous punctation large and dense; setae moderately long and yellow; on average, interstices between punctures less than half as wide than diameter of punctures; without microsculpture; surface slightly shiny.

Abdomen with similar dense and deep punctation as on elytra; setae also moderately long and yellow.

Protibia with five spines at outer edge and few setae on posterior face.

Aedeagus elongate; with smoothly curved apical lobe; paramera slightly shorter than apical lobe; at apex with two long setae; endophallus narrow; with two long coils at base and one short coil at apex.

Diagnosis: $N$. pecki is the smallest species of the genus. In contrast to $N$. brasiliensis and $N$. lutzi, it is lighter yellow. Concerning the shape of the pronotum, it resembles $N$. brasiliensis, but the surface is shinier due to the less deep microsculpture. Compared to $N$. lutzi, the pronotum of $N$. pecki has no emargination in front of the posterior angles.

\section{Neorhabdopsis lutzi spec. nov. (Figs 7A-C, 16C)}

Type material: Holotype male: Panama, Barro Colorado, C.Z., Nov. 1930, leg. F.E. Lutz (AMNH).

Paratypes: 2 males, 3 females, with same data as holotype (AMNH, UIC).

Etymology: The specific name is given to honor the collector of the species.

Description: Length: $1.7 \mathrm{~mm}$. Colouration: Yellow; legs and antennae slightly lighter yellow.

Head: $0.19 \mathrm{~mm}$ long, $0.33 \mathrm{~mm}$ wide; fore-head semicircular; setiferous punctation dense and deep; on average, interstices between punctures half as wide as diameter of punctures; remains of netlike microsculpture; surface moderately shiny.

Antennae slightly longer than head and half of pronotum combined; first antennomere rectangular; second 
oval; third conical and slightly narrower than second; following antennomeres wider than long and increasing in width; fourth antennomere slightly wider than long, nearly quadrate; tenth antennomere 1.5 times wider than long.

Pronotum: $0.32 \mathrm{~mm}$ long, $0.39 \mathrm{~mm}$ wide; widest in the middle; slightly narrowed to anterior angles; in posterior half more strongly narrowed and with emargination in front to posterior angles; posterior angles distinct; lateral margin fine; in dorsal aspect, visible throughout its total length except shortly behind anterior angles; setiferous punctation large and coarse; on average, yellow setae twice as long as diameter of punctures; on average, interstices between punctures less than half as wide as diameter of punctures; narrow irregular midline impunctate; without microsculpture; surface moderately shiny.

Elytra: $0.29 \mathrm{~mm}$ long, $0.39 \mathrm{~mm}$ wide, widest in posterior third; setiferous punctation as large and coarse as on pronotum and with similar setae; without microsculpture; surface moderately shiny. Abdomen with similarly large punctation as on pronotum and elytra; punctation even denser than on elytra.

Protibia enlarged, but relatively slender; outer edge with five fine spines and few setae.

Aedeagus thick; apical lobe in rectangular angle to basal lobe; paramera shorter than apical lobe and with long apical seta; endophallus with several coils in middle, straight apical part, and irregular coils at lateral part.

Diagnosis: The species can be easily separated from the two other described species by the distinct emargination in front of the posterior pronotal angles.

\section{Neorhabdopsis panamae spec. nov.} (Figs 8A-C, 16D)

Type material: Holotype male: Panama, Colon, Parque Nac. Soberania Pipeline Rd. $\left(79^{\circ} 45^{\prime} \mathrm{W}, 9^{\circ} 07^{\prime} \mathrm{N}\right)$, collected from soil/leaf litter, 23.05.1995, leg. J. Jolly \& C. Chaboo (KNHM).

Etymology: The specific name derived from the country where the species was collected.
Description: Length: $1.7 \mathrm{~mm}$. Colouration: reddish; legs and antennae yellow.

Head: $0.23 \mathrm{~mm}$ long, $0.32 \mathrm{~mm}$ wide; without eyes; clypeus semicircular; labrum rectangular; setiferous punctation coarse and dense; punctures large; interstices between punctures one fourth as wide as diameter of punctures; on small parts of vertex and at base of antennae wider; without microsculpture; surface shiny.

Antennae slightly shorter than head and pronotum combined; first antennomere approximately rectangular; second antennomere nearly as thick as first, but oval; third antennomere conical and slightly narrower than second; following antennomeres increasing in width; fourth antennomere nearly quadrate; tenth antennomere nearly twice as wide as long.

Pronotum: $0.30 \mathrm{~mm}$ long, $0.37 \mathrm{~mm}$ wide; widest in middle; slightly narrowed to anterior angles; more strongly convergent to posterior angles; lateral margin extremely fine; in dorsal aspect, only visible in short part close to posterior angles; posterior angles nearly rectangular; setiferous punctation coarse and dense; more homogeneous than on head; punctures large; interstices between punctures less than half as wide as diameter of punctures; narrow midline impunctate; setae longer than diameter of two punctures; pointing transversely to posterior middle; interstices and punctures with netlike microsculpture; surface shiny.

Elytra: $0.29 \mathrm{~mm}$ long, $0.37 \mathrm{~mm}$ wide; along suture impressed; setiferous punctation as coarse as on pronotum; punctures as large as on pronotum; interstices between punctures slightly wider than on pronotum; netlike microsculpture as on pronotum; surface shiny. Abdomen slightly widened from abdominal segment III to VII; setiferous punctation similar as on pronotum; on posterior segments less dense than on anterior segments; microsculpture as on pronotum; surface shiny.

Protibia slightly widened; with few spines on outer edge; tarsae of all legs with five tarsomeres.

Aedeagus with shortly curved apical lobe ending in short acute apex; paramera not longer than apical lobe and with one long seta; spiral endophallus with several torsions.

Diagnosis: The species is separated from the other three species of the genus by the longer elytra. In contrast to the

\section{Key to species of the genus Neorhabdopsis}

1. Pronotum without slight emargination in front of posterior angles

Pronotum with distinct emargination in front of posterior angles N. lutzi spec. nov.

2. Elytra nearly twice as wide as long, smaller, $1.5 \mathrm{~mm}$ long N. pecki spec. nov. Elytra longer, length: width ratio at least 0.7 , larger, $1.7 \mathrm{~mm}$ long 3

3. With deep microsculpture, punctation sparser, interstices between punctures half as wide as diameter of punctures $N$. brasiliensis spec. nov.

With weak microsculpture, punctation deeper and denser, interstices between punctures less wide than half of diameter of punctures N. panamae spec. nov. 
other three species, the elytra of $N$. panamae are nearly quadrate. The length: width ratio is 0.8 , whereas it is 0.7 or 0.6 in the other three species.

\section{Tumboecus verhaaghi spec. nov.}

(Figs 9A-C, 15E)

Type material: Holotype male: Peru, Huanuco, Panguana (7456'W, 9³7'S), pitfall trap, male, 3.-18.06.1984, leg. M. Verhaagh (UIC).

Paratypes: female with same data as holotype; Peru, Huanuco, Panguana, rainforest, 1 male, 1 female, 20.05 . 1984, leg. M. Verhaagh; rainforest, 4 females, Feb. 1975, 06.05.1975, 08.-09.1975, 10.-11.1975 leg. W. Hanagarth; grassland, female, 03.09.1975, leg. W. Hanagarth; cut rainforest planted with manioc, female, 20.03.1975, leg. W. Hanagarth (UIC).

Etymology: The specific name is given in honor of the collector of the species to whom the species is heartily dedicated.

Description: Length: $1.5 \mathrm{~mm}$. Colouration: brown; legs and antennae light brown.

Head: $0.18 \mathrm{~mm}$ long, $0.31 \mathrm{~mm}$ wide; eyes large, not prominent; longer than temples; sides of forehead strongly convergent; anterior edge of clypeus even; setiferous punctation dense and coarse; neck without punctation; weak microsculpture netlike; surface moderately shiny.

Antennae nearly as long as head and pronotum combined; first antennomere thick; as thick as fourth antennomere; second narrower and oval; third antennomere conical; following antennomeres increasing in width; fourth to ninth wider than long; tenth antennomere approximately quadrate.

Pronotum: $0.31 \mathrm{~mm}$ long, 0.36 wide; widest at anterior angles; moderately narrowed to posterior angles in anterior half; more strongly narrowed in posterior half; in front of posterior angles more strongly narrowed; lateral margin fine; in dorsal aspect covered in anterior half; setiferous punctation coarse and large; interstices between punctures irregularly wide; on average, half as wide as diameter of punctures; in lateral posterior half, interstices wider; without microsculpture; surface shiny.

Elytra: $0.39 \mathrm{~mm}$ long, $0.38 \mathrm{~mm}$ wide; shoulders approximately rectangular; sides subparallel; slightly widened posteriorly; setiferous punctation large and dense; on average, interstices as wide as or slightly shorter than diameter of punctures; with remains of microsculpture; surface shiny.

Abdomen with similar setiferous punctation and similar microsculpture as on fore-body.

Protibia only slightly enlarged; with four spines on outer edge inserting directly on edge; in posterior aspect, comb at inner emargination totally visible; posterior face with several setae; tarsae pentamere.
Aedeagus short and stout; without paramera; apical lobe in rectangular angle to basal lobe; apex moderately acute; endophallus with one torsion.

Diagnosis: The two species T. verhaghi and T. struyvei are extremely similar regarding the punctation and shape of the pronotum. T. verhaaghi is slightly smaller than T. struyvei and the endophallus is different. Furthermore, the surface of T. verhaaghi is shinier, in particular, the surface of the pronotum.

\section{Tumboecus struyvei spec. nov}

(Figs 10A-C, 15F)

Type material: Holotype male: French Guyana, Caussade $\left(52^{\circ} 35.29^{\prime} \mathrm{W}, 5^{\circ} 03.57^{\prime} \mathrm{N}\right)$, sampled by car-net, 7.11.2011, leg. T. Struyve (UIC).

Paratypes: 1 male, 1 female with same data as holotype (UIC, TSC).

Etymology: The specific name was chosen to honour the collector T. Struyve.

Description: Length: $2.1 \mathrm{~mm}$. Colouration: light brown; head and abdomen slightly darker than pronotum and elytra; legs and antennae yellow.

Head: $0.20 \mathrm{~mm}$ long, $0.35 \mathrm{~mm}$ wide; eyes large, but not prominent; longer than temples; fore-head semi-circular; setiferous punctation dense and coarse; on average, interstices between punctures half as wide as diameter of punctures; at middle of fore-head interstices slightly wider; netlike microsculpture weak; irregularly dense; surface shiny.

Antennae as long as head and half of pronotum combined; first antennomere thick and oval; second oval and slightly narrower and shorter than second; following antennomeres wider than long; sixth antennomere nearly three times wider than long; seventh antennomere thicker than sixth, but only 1.5 times wider than long.

Pronotum: $0.36 \mathrm{~mm}$ long, $0.39 \mathrm{~mm}$ wide; widest at anterior angles; evenly narrowed to posterior angles, but in posterior half stronger narrowed than in anterior half; posterior angles obtuse; nearly rectangular; lateral margin fine; visible throughout its total length; setiferous punctation coarse and dense; on average, interstices between punctures half as wide as diameter of punctures; wide midline impunctate; netlike microsculpture weak and irregularly dense; surface slightly less shiny than head. Elytra: $0.45 \mathrm{~mm}$ long, $0.40 \mathrm{~mm}$ wide; widest in posterior third, but more or less subparallel; setiferous punctation weaker than on pronotum; netlike microsculpture weak and irregularly dense.

Abdomen with setiferous punctation; punctures as coarse as on fore-body; midline on tergites impunctate.

Protibia slender with few spines on outer edge; inner emargination distinct; in posterior aspect, comb visible throughout its total length; posterior face with long setae. 
Aedegus thick; apical lobe in rectangular angle to basal lobe; apical lobe obtuse at apex; without paramera; endophallus slightly curved and divided into two branches.

Diagnosis: The differences are already given in the description of T. verhaaghi.

\section{Oryssoma politum spec. nov.}

(Figs 4A-D, 15C)

Type material: Holotype male: Ecuador, Napo Prov., Jatun Sacha Biol. Stat., $21 \mathrm{~km}$ E. Puerto Napo $\left(77^{\circ} 37.42 \mathrm{~W}, 1^{\circ} 03.57 \mathrm{~S}\right), 400 \mathrm{~m}$ elevation, lowland rain forest, collected by flight intercept trap, 21.07.1994, leg. F. Génier (KNHM).

Paratypes: Ecuador, Napo Prov., 1 female with same data as holotype (KNHM); Sacha Lodge $\left(76^{\circ} 27.32^{\prime} \mathrm{W}, 0^{\circ} 28.15^{\prime} \mathrm{S}\right)$ $250 \mathrm{~m}$ elevation, collected by flight intercept trap, female, 26.-28.10.2004, leg. G. de Rougemont (UIC).

Etymology: The specific name derived from the same Latin name meaning polished and refers to the polished surface.

Description: Length: $3.0 \mathrm{~mm}$. Colouration: Black, pronotum slightly lighter, dark brown, legs and antennae light brown; labrum and small area at base of antennae light reddish; abdomen reddish.

Head: $0.36 \mathrm{~mm}$ long, $0.52 \mathrm{~mm}$ wide; eyes distinctly prominent; semi-circular, temples half as long as eyes; sides in front of eyes shortly parallel; then abruptly narrowed in sinuate curve to anterior angles of clypeus; anterior edge of clypeus produced in semi-circular curve; labrum semicircular, too; punctation weak and sparse; one setiferous puncture in front of eyes and another setiferous punctures on vertex close to eyes; supraocular puncture distinctly impressed; without microsculpture; surface polished and shiny.

Antennae as long as head and half of pronotum combined; second antennomere elongate, oval; as long as two following antennomeres; following antennomeres increasing in width; third and fourth antennomeres narrower than second antennomere and approximately quadrate; fifth and sixth antennomeres distinctly wider than long; sixth antennomere twice as wide as long; following antennomeres distinctly thicker than preceding antennomeres and approximately 1.5 times wider than long.

Pronotum: $0.45 \mathrm{~mm}$ long, $0.53 \mathrm{~mm}$ wide; widest shortly behind anterior angles; slightly narrowed to posterior angles; shortly in front of posterior angles emarginate; lateral margin fine; in dorsal aspect, visible in its total length; continued to posterior edge; punctation sparse and irregular in size; with moderately fine punctures and micro-punctures; along lateral margin and anterior edge with several setiferous punctures; pair of setiferous punctures on posterior disc close to posterior margin; without microsculpture; surface polished and shiny.
Elytra: $0.65 \mathrm{~mm}$ long, $0.58 \mathrm{~mm}$ wide; sides parallel; shoulders distinct, but rounded; punctation weak and sparse; punctation nearly invisible in deep coriaceous groundsculpture; row of four setiferous punctures along lateral margin; further setiferous punctures along posterior edge and on disc; surface shiny.

Abdomen finely and sparsely punctate; each segment with transverse row of setiferous punctures; segments seven and eight with two rows of setiferous punctures; without micro-sculpture; surface polished and shiny. Protibia: $0.39 \mathrm{~mm}$ long, $0.10 \mathrm{~mm}$ wide; eight spines on outer edge; apical spines inserted on short digits; on posterior face with second row of four spines and with several long yellow setae; three tarsomeres; first elongate; nearly twice as long as second; inner emargination with comb visible in its total length.

Aedeagus with long basal lobe and much shorter apical lobe; apical lobe forming short hook ending in acute apex; paramera short, but slightly longer than apex of apical lobe; endophallus creased and spiralled.

Diagnosis: Among the three species of Oryssoma, O. politum can be easily identified by the thick prominent eyes. In O. exalatus and O. schwarzi the eyes are not prominent and smaller. The penultimate antennomeres are wider in O. politum than in the two other species. The pronotum of $O$. politum is slightly emarginate in front of the posterior angles and with impressions, whereas it is without emargination and impressions in O. exalatus and $O$. schwarzi.

Oryssoma exalatum (BLACKWELDER, 1943) new comb. (Figs 3A-C, 15D)

Osorius exalatus BLACKWELDER, 1943: 200

Type material examined: Holotype male: Trinidad, Cave in Aripo Valley, $600 \mathrm{~m}$ elevation, 18.04.1935, leg. N.A. Weber (MCZ).

Description: Length: $2.3 \mathrm{~mm}$. Colouration: light brown, legs and antennae yellow.

Head: $0.42 \mathrm{~mm}$ long, $0.50 \mathrm{~mm}$ wide; eyes not prominent, temples nearly twice as long as eyes; in front of eyes, fore-head slightly narrowed to base of antennae, then emarginate and strongly narrowed; clypeus produced in semi-circular curve; labrum semi-circular, too; punctation moderately deep and dense; on average, interstices between punctures twice as wide as diameter of punctures; on posterior vertex slightly denser than on fore-head; netlike microsculpture weak; surface shiny.

Antennae slightly longer than head; second antennomere thick and elongate, twice as long as wide and nearly two times longer than conical third antennomere; following antennomeres increasing in width; third and fourth antennomeres narrowed than second; fifth approximately 
as thick as second; fourth to tenth antennomere approximately quadrate, only fifth slightly wider than long. Pronotum: $0.46 \mathrm{~mm}$ long, $0.56 \mathrm{~mm}$ wide; widest at anterior angles; narrowed posteriad in smooth and even curve; without forming posterior angles; lateral margin fine; in dorsal aspect visible in total length; posterior edge margined; punctation irregular in size; moderately dense; on average, interstices between punctures at least as wide as diameter of punctures; netlike microsculpture weak; surface shiny.

Elytra: $0.43 \mathrm{~mm}$ long, $0.54 \mathrm{~mm}$ wide; widest close to posterior angles; evenly narrowed to shoulders; shoulders obtuse; three setiferous puncture close to lateral margin; one setiferous puncture on anterior disc on each side of suture; punctation indistinct; with coriaceous groundsculpture; surface shiny.

Abdomen with dense transverse netlike microsculpture and moderately deep and dense punctation; each segment with transverse row of setiferous punctures.

Protibia slender; with seven spines on outer edge; apex with two very long spines; posterior face with six spines and several setae; first tarsomere with two long and thick setae at apex.

Aedaegus slender; basal lobe thick and long; apical lobe shorter and curved like short hook ending in acute apex; paramera not longer than apex of apical lobe.

Diagnosis: The species is only known from the single type male found in a cave in Trinidad. Concerning the trimere tarsae, the shape of the labrum and the structure of the aedeagus the species has to be placed to the genus Oryssoma together with O. schwarzi and O. politum. It can be easily differentiated from these two species by the short elytra and the nearly semi-circular shape of the pronotum. It is not clear, if the light brown colouration can be referred to the life in a cave or the immature status of the specimen. fore, a thorough comparison between the two species was impossible. I found no further difference between the species as did BLACKWELDER (1943). Thus, it is likely that $O$. microptera is the female of O. exalatum. But synonymisation has to wait until more material of the two species is available.

\section{Osoriosetus hanagarthi spec. nov.}

(Figs 11A-C, 17A)

Type material: Holotype male: Peru, Huanuco, Panguana (7456'W, 9³7'S), Cocha, May 1975, leg. W. Hanagarth (UIC).

Paratypes: Panguana $\left(74^{\circ} 56^{\prime} \mathrm{W}, 9^{\circ} 37^{\prime} \mathrm{S}\right)$, river margin, female, 05.01.1976, leg. W. Hanagarth (UIC).

Etymology: The species is named in honour of my dear colleague Dr. Werner Hanagarth, who unfortunately passed away too early. Among the extensive material collected by him in Panguana, this interesting species was found, which could not be integrated in one of the described genera.

Description: Length, $5.3 \mathrm{~mm}$; colouration, black; legs and antennae light brown.

Head: $0.67 \mathrm{~mm}$ long, $0.90 \mathrm{~mm}$ wide; eyes small, but prominent; temples nearly three times longer than eyes; sides of fore-head narrowed to anterior angles in short concave curve; anterior edge of clypeus even; slightly convex; setiferous punctation coarse and dense; on average, interstices between punctures less than half of diameter of punctures; setae short; not much longer than one interstice between punctures; small area at antennae and large transverse area on neck impunctate; on punctate areas with isodiametric deep microsculpture; surface matt; impunctate areas shiny.

\section{Key to species of the genus Oryssoma}

1. Eyes thick and prominent; semicircular O. politum spec. nov. Eyes not prominent 2

2. Posterior angles of pronotum widely rounded; elytra wider than long 3

Posterior angles of pronotum nearly rectangular; elytra longer than wide O. schwarzi Notman, 1925

3. Front of clypeus angulate O. exalatum (BLACKWELDER, 1943) Front of clypeus rounded O. microptera (BLACKWELDER, 1943)

\section{Oryssoma microptera (BLACKWELDER, 1943)}

\section{Osorius micropterus BLACKWELDER, 1943}

Blackwelder's type was studied. Unfortunately, it is a female. Furthermore, Blackwelder separated O. exalatum from $O$. microptera only by the shape of the clypeus. The type specimen of O. microptera has lost the head. There-
Antennae slightly longer than head; second antennomere elongate; 1.5 times as long as wide; conical third antennomere distinctly shorter than second; following antennomeres increasing in width; fourth antennomere slightly longer than wide; tenth antennomere quadrate. Pronotum: $1.02 \mathrm{~mm}$ long, $1.02 \mathrm{~mm}$ wide; widest close to anterior angles; anterior angles obtusely rounded; very slightly narrowed posteriad; in posterior half with indis- 
tinct concave emargination; shortly in front of posterior angles with deep concave emargination; lateral margin fine; in dorsal aspect, visible throughout its total length; margin continued to posterior edge; setiferous punctation deep and dense; along midline much denser than laterad; partly forming short furrows; on lateral disc, interstices between punctures as wide as diameter of punctures; within impunctate midline with deep elongate impression; between coarse punctation with dense micro-punctation; without microsculpture; surface polished and shiny.

Elytra: $1.05 \mathrm{~mm}$ long, $1.10 \mathrm{~mm}$ wide; widest in posterior third; shoulders rectangular, but rounded; setiferous punctation deep and moderately dense; in indistinct rows; on average, interstices between punctures twice as long as diameter of punctures; coriaceous microsculpture weak; surface moderately shiny.

Abdomen with regular punctation; setiferous punctation dense and deep; interstices between punctures approximately half as wide as diameter of punctures; setae slightly longer than interstices between punctures; deep netlike microsculpture; surface matt.

Protibia: $0.62 \mathrm{~mm}$ long, $0.25 \mathrm{~mm}$ wide; shape semicircular; outer edge with 13 spines in approximately equal distances from each other; not inserted on digits; posterior face densely covered by yellow setae; in posterior aspect, inner emargination with comb totally covered.

Aedaegus without endophallus; thick; apical lobe placed in obtuse angle to basal lobe; apical third also angled and narrowed to obtuse apex.

Diagnosis: At present only this species is known from the genus that is characterised by the unique structure of the protibia. It mostly resembles some species of Osoriellus, but the total coverage of the inner emargination is never found in Osoriellus.

\section{Neosorius brasiliensis spec. nov. (Figs 12A-C, 16E)}

Type material: Holotype male: Brazil, Minas Gerais, Govenador Valadares $\left(41^{\circ} 56^{\prime} \mathrm{W}, 18^{\circ} 51^{\prime} \mathrm{S}\right)$, leaf litter, 26.3.1981, leg. L. Sorkin (AMNH).

Paratype: Brazil, Rio de Janeiro, Ipanema, collected by light fixture, female, 13.9.1982, leg. L. Sorkin (UIC).

Etymology: The specific name is derived from the country, where the species was found.

Description: Length: $4.4 \mathrm{~mm}$. Colouration: Black; legs reddish brown, antennae slightly lighter reddish brown. Head: $0.67 \mathrm{~mm}$ long, $0.92 \mathrm{~mm}$ wide; eyes prominent; as long as temples; sides of fore-head narrowed to anterior angles of clypeus in slight concave curve; anterior edge of clypeus even; surface of clypeus finely, but distinctly striate; vertex with coarse longitudinal striae ending on line with posterior edge of eyes; neck without striae; only with fine transverse micro-reticulation; within striae sparse setiferous punctation; setae as long or slightly longer than interstices between punctures; small area at base of antennae without punctures and striae; surface matt.

Antennae slightly shorter than head and half of pronotum combined; second antennomere oval; nearly twice as long as wide; third antennomere conical and slightly shorter than second; following antennomere increasing in width, but all approximately quadrate or slightly wider than long.

Pronotum: $0.85 \mathrm{~mm}$ long, $1.00 \mathrm{~mm}$ wide; widest shortly behind anterior angles; anterior angles obtuse; sides narrowed to posterior angles in smooth convex curve; posterior angles obtuse and smoothly rounded; lateral margin fine; in dorsal aspect covered close to anterior angles; continued to posterior margin; setiferous punctation moderately dense and deep; on average, interstices between punctures as wide as diameter of punctures; between normal punctation with fine micro-punctation; without microsculpture; surface shiny.

Elytra: $1.07 \mathrm{~mm}$ long, $1.04 \mathrm{~mm}$ wide; widest in posterior third; shoulders rectangular, but rounded; setiferous punctation as dense and deep as on pronotum; coriaceous ground-sculpture weak; surface shiny.

Abdomen with moderately dense setiferous punctation; punctures finer than on elytra and pronotum; narrow midline impunctate; netlike microsculpture weak; surface less shiny than on pronotum.

Protibia: $0.53 \mathrm{~mm}$ long, $0.13 \mathrm{~mm}$ wide; with seven spines on outer edge; apical spines on long digits; WLR: 0.56 ; between spine two and three at apex with wider interstice than between other spines; posterior face with row of five spines; apical spines inserting on short digits; between spines with sparse setation; in posterior aspect, inner emargination with comb totally visible.

Aedeagus with thick apical lobe; suddenly narrowed to obtuse apex; endophallus spiralled with three torsions.

Diagnosis: The species is characterised by the longitudinal striae of the head and the smoothly curved sides of the pronotum. Additionally, it is distinctly smaller than N. mexicanus. According to the descriptions of FAGEL (1959) it resembles species of the African Neosorius of the arebianus-group.

\section{Neosorius mexicanus spec. nov (Figs 13A-C, 16F)}

Type material: Holotype male: Mexico, without further data, leg. Skwara (NMPC).

Paratypes: two females with same data as holotype (NMPC, UIC)

Etymology: The specific name derived from the name of the country, where the species was found. 
Description: Length: $6.0 \mathrm{~mm}$. Colouration: Black; legs and antennae brown.

Head: $1.03 \mathrm{~mm}$ long, $1.16 \mathrm{~mm}$ wide; eyes slightly prominent; temples approximately 1.5 times longer than eyes; fore-head narrowed to anterior angles of clypeus in long slight concave curve; anterior edge of clypeus deeply emarginate; thus, clypeal angles produced to broad triangles; clypeus with large elongate coriaceous punctures; on vertex similarly coarse elongate punctation separated by narrow impunctate midline; large area at base of antennae impunctate; continued to middle and separating clypeal punctation from vertex punctation; punctures of clypeus and vertex with setae; impunctate areas without microsculpture; overall surface matt, but impunctate areas shiny.

Antennae slightly longer than head; second antennomere elongate; slightly longer than wide; third antennomere conical and as long as second; following antennomeres increasing in width, but all approximately quadrate or slightly wider than long.

Pronotum: $1.08 \mathrm{~mm}$ long, $1.29 \mathrm{~mm}$ wide; widest in anterior third; smoothly narrowed to obtuse anterior angles; more distinctly narrowed to posterior angles; in front of posterior angles sinuate; posterior angles rectangular; lateral margin narrow; in dorsal aspect, lateral margin covered close to anterior angles; thicker close to posterior angles and continued to posterior edge; setiferous punctation deep and moderately dense; close to impunctate midline denser than laterad; on average, close to midline interstices between punctures half as wide as diameter of punctures; laterally, interstices between punctures as wide as diameter of punctures; between normal punctation with fine micro-punctures; without microsculpture; surface shiny.

Elytra: $1.28 \mathrm{~mm}$ long, $1.26 \mathrm{~mm}$ wide; widest in posterior third; shoulders rectangular, but rounded; setiferous punctation dense and deep; on average; interstices between punctures slightly shorter than diameter of punctures; coriaceous ground-sculpture weak; surface moderately shiny.

Abdomen with dense and fine setiferous punctation; punctures distinctly finer than on elytra; setae as long as two interstices between punctures; netlike microsculpture weak; surface moderately shiny.

Protibia: $0.74 \mathrm{~mm}$ long, $0.17 \mathrm{~mm}$ wide; with nine spines on outer edge; apical spines on moderately short digits; WLR: 0.65 ; on posterior face with row of five spines inserting on short digits; between spines sparsely covered by long yellow setae; in posterior aspect, inner emargination with comb totally visible.

Aedeagus with long apical lobe; broad at base; then suddenly narrowed to long small apex; apex slightly sinuate; at base of lateral apical lobe with numerous sensillae; endophallus smoothly spiralled; with only two torsions.
Diagnosis: The species can be easily identified by the deep emargination of the clypeus and the posteriad sinuate sides of the pronotum.

\section{Paratorchus McCoLL, 1985 \\ Paratorchus brasiliensis (BERnhaueR \& SCHUBERT, 1910) comb. nov. \\ (Figs 18B, 19H)}

Holotrochus brasiliensis BernHAUER \& SCHUBERT, 1910: 142 Holotrochus brevipennis BernhaueR, 1905: 15

Distribution: Brazil, Såo Paulo, Santos, leg. Müller (FMNH); Såo Paulo, 26.02.1969 leg. J.M. Campbell (CBI).

\section{Paratorchus bolivianus (IRMLER, 2005) comb. nov. (Figs 19A, I)}

Holotrochus bolivianus IRMLER, 2005: 9

Distribution: Bolivia, Cochabamba, $82 \mathrm{~km}$ E. Yungas, Rio Vineto, 03.02.1998, leg. R. Anderson (KNHM, UIC); 82 km E. Yungas, Villa Tunari, 06.02.1998, leg. R. Anderson (KNHM); Lagunitas, 117 km E. Young as, 01.02.1998, leg. R. Anderson (KNHM); La Paz, Chulumani, Apa Apa, 17.01.2001, leg. R. Anderson (KNHM, UIC); 9.4 km E. Apa Apa, 19.01.2001, 21.01.2001, leg. R. Anderson (KNHM, UIC); $6 \mathrm{~km}$ W. El Paraiso, 20.01.2001, leg. R. Anderson (KNHM); Buena Vista, Hotel Flora y Fauna, 09.11.2002, leg. R. Leschen (KNHM); Zongo valley, 30.01.2001, leg. R. Anderson (KNHM).

\section{Paratorchus breviatus (IRMLER, 2007) comb. nov.}

(Figs 19B, K)

Holotrochus breviatus IRMLER, 2007: 136

Holotrochus curtipennis IRMLER, 2005: 12

Distribution: Ecuador, Azuay, Cuenca, Acuay, 07.01.1992, leg. J.S. Ashe (KNHM, UIC); Marzan Forest, 16.04.1990, leg. C.E. Carlton (KNHM).

Paratorchus panamae (IRMLER, 2005) comb. nov. (Figs 18E, 19E)

Holotrochus panamae IrmLeR, 2005: 16

Distribution: Mexico, Chiapas, Montepio, Angel Albino Corzo, 21.11.2001, leg. R. Anderson (KNHM, UIC); Costa Rica, Heredia, La Virgen, 1.2 km E., 28.03.1991, leg. L. Herman (AMNH) San José, 18 km N. San Isidro de el General, 15.02.1998, 20.06.1997, 25.06.1997, leg. 
R. Anderson (KNHM, UIC); $23 \mathrm{~km} \mathrm{~N}$. San Isidro de el General, 20.06.1997, leg. R. Anderson (KNHM); San Gerardo de Dota, Cordilliera de Talamanca, 13.01.2005, leg. M. Schülke (MSC); Puntarenas, Los Cruces, Biol. Stat. 19.06.1998, leg. R. Anderson (KNHM); $11 \mathrm{~km}$ SW. Biol. Stat. Las Cruces, 09.07.1999, leg. R. Anderson (KNHM); San Vito, 2 km N Alturas, Biol. Stat. 21.06.1998, leg. R. Anderson (KNHM); $35 \mathrm{~km} \mathrm{NE.} \mathrm{Las} \mathrm{Alturas,}$ 19.03.1991, leg. L. Herman (AMNH); Alajuela, San Ramón, 27 km N. 8 km W., 29.04.1999, leg. R. Anderson (KNHM, UIC); Panama, Chiriqui, Boquete, $6 \mathrm{~km} \mathrm{NE.}$ 14.06.1996, leg. R. Anderson (KNHM, UIC); La Fortuna, Continental Divide Trail, 09.06.1995, leg. R. Anderson (KNHM).

Paratorchus columbiensis (lRMLER, 1987) comb. nov. (Figs 18D, 19G)

Holotrochus columbiensis IRMLER, 1987: 102

Distribution: Columbia, Valle del Cauca, Valle Soladito, 20.07.1970, leg. J.M. Campbell (CBI); Venezuela, Aragua, Maracay, Rancho Grande, Biol. Stat. 12.05.1998, 13.05.1998, 14.05.1998, leg. R. Anderson (KNHM, UIC); 28.02.1995, leg. R.W. Brooks (KNHM, UIC); 22.03.1992, 15.04.1994, leg. L. Herman (AMNH); Parq. Nat. H. Pittier, 20.04.2005, leg. C. Csuzdi (NHB); Mérida, Portachuelo, Parque Pittier, 15.02.1987, leg. M.G. Paoletti (AMNH).

Paratorchus chilensis (IRMLER, 2005) comb. nov. (Figs 18C, 19D)

Holotrochus chilensis IRMLER, 2005: 10

Distribution: Chile, Aysen, San Juan de Chadmo, 18.02.1997, 20.02.1997, leg. T. Cekalovic (KNHM, UIC); Los Lagos, Llanquihue, 20.02.1983, 23.02.1997, leg. T. Cekalovic (KNHM, UIC); Isla Chiloe, Coinco, 14.02.1983, leg. T. Cekalovic (KNHM); Lago Huillinco, 31.01.1983, leg. T. Cekalovic (AMNH); Vilupulli, 7.02.1981, 18.02.1983, leg. T. Cekalovic (AMNH); Ancud, 27.01.1983, 10.02.1981, leg. T. Cekalovic (AMNH, UIC); Chiloe, 10.02.1981, 27.01.1983, leg. T. Cekalovic (AMNH,
UIC); Osorno, 48 km W., 28.11.1994, leg. R. Leschen (KNHM, UIC); 58.5 km W., 12.11.1994, leg. R. Leschen (KNHM); $14.5 \mathrm{~km} \mathrm{W.,} \quad 12.01 .1994$, leg. R. Leschen (KNHM); Conchi, 26.11.1994, leg. R. Leschen (KNHM); Quetro, Isla Quinchao, 19.02.1997, leg. T. Cekalovic (AMNH); Chepu, 21.02.1997, leg. T. Cekalovic (KNHM, UIC); Chepu, 02.10.1958, 09.10.1958, 10.10.1958, 14.10.1958, leg. F. Kuschel (BMNH); Puente, 28.02.1997, leg. T. Cekalovic (KNHM); Puente La Caldera, 18.02.1997, leg. T. Cekalovic (KNHM); Maiocolpue, Valdivia forest, 21.12.1982, leg. A. Newton (FMNH); 26.01.1986, leg. R.T. Schuh (AMNH, UIC).

Paratorchus chiriquensis (IRMLER, 2005) comb. nov. (Figs 18F, 19F)

Holotrochus chiriquensis IRMLER, 2005: 11

Distribution: Costa Rica, Puntarenas, Las Alturas, San Vito Biol. Stat., 21.06.1998, leg. R. Anderson (KNHM, UIC); Los Cruces, $4 \mathrm{~km} \mathrm{S.} \mathrm{Biol.} \mathrm{Stat.,} \mathrm{18.06.1998,}$ 22.06.1998, leg. R. Anderson (KNHM, UIC); $35 \mathrm{~km} \mathrm{NE.}$ Las Alturas, 19.03.1991, leg. L. Herman (AMNH).

\section{Paratorchus tilli spec. nov.}

(Figs 14A-C, 18A, 19C)

Type material: Holotype male: Mexico, Veracruz, $1 \mathrm{mi}$ S Huatusco, $1344 \mathrm{~m}$ elevation, collected by Berlese, 02.08.1969, leg. S. \& J. Peck (AMNH).

Paratypes: Two females with same data as holotype (AMNH, UIC).

Etymology: The specific name of this small species derived from the name of my little grand son Till.

Description: Length: $2.8 \mathrm{~mm}$. Colouration: light reddish brown; legs and antennae lighter brown.

Head: $0.35 \mathrm{~mm}$ long, $0.49 \mathrm{~mm}$ wide; without eyes; fore-head approximately semicircular; anterior edge of clypeus even; punctation moderately dense and deep; on average, interstices between punctures at least as wide as diameter of punctures; on disc two times as wide as

\section{Key to the species of Paratorchus}

1. Blind, abdomen not pubescent P. tilli spec. nov.

At least with few omatidia 2

2. Abdomen pubescent 3

Abdomen not pubescent 6

3. Sides of pronotum evenly narrowed from middle to posterior angles, posterior angles obtuse P. brasiliensis (BERNHAUER \& SCHUBERT, 1910)

Sides of pronotum nearly parallel in posterior half 4 
4. Large species of at least $3.0 \mathrm{~mm}$ length, sides of pronotum parallel, not sinuate in front of posterior angles ....... 5 Small species of 2.5 least, sides of pronotum at least slightly sinuate in front of posterior angles

P. panamae (IRMLER, 2005)

5. Sides of pronotum evenly rounded, pronotal punctation deeper and denser, interstices between punctures as wide as diameter of punctures P. bolivianus (IRMLER, 2005)

Sides of pronotum slightly sinuate in middle, pronotal punctation finer and sparser, interstices between punctures much wider than diameter of punctures P. columbiensis (IRMLER, 1987)

6. Large species of at least $4.0 \mathrm{~mm}$ length P. breviatus (IRMLER, 2007)

Smaller species of 2.5 to $2.8 \mathrm{~mm}$ length 7

7. Pronotum deeply and densely punctate, surface polished without microsculpture, shiny P. chiriquensis (IRMLER, 2005)

Pronotum finely and sparsely punctate, surface with netlike microsculpture, matt P. chilensis (IRMLER, 2005)

diameter; laterally with few setae; setae extremely short; without microsculpture; between normal punctures with sparse micro-punctation; temples with deep netlike microsculpture.

Antennae as long as head and half of pronotum combined; first antennomere thick; thicker than second oval and conical third antennomere; second and third antennomere equal in length and longer than following antennomeres; antennomeres four to eleven increasing in width; fourth longer than wide; tenth nearly twice as wide as long; surface polished and shiny.

Pronotum: $0.51 \mathrm{~mm}$ long, $0.64 \mathrm{~mm}$ wide; widest in anterior third; slightly narrowed to anterior angles in convex curve; in posterior two third evenly narrowed to posterior angles; nearly parallel; posterior angles rectangular; lateral margin distinct; in dorsal aspect visible throughout its total length; at posterior angles with indistinct impression; punctation deeper and denser than on head; on average, interstices between punctures as wide as diameter of punctures; between coarse punctures with sparse micro-punctation; with irregular microsculpture; surface less shiny than on head.

Elytra: $0.37 \mathrm{~mm}$ long, $0.67 \mathrm{~mm}$ wide; sides slightly widened to posterior angles; shoulders rectangular; posterior edge slightly emarginate; punctation still deeper and coarser than on pronotum; partly coriaceous; with coriaceous ground-sculpture; surface less shiny than on pronotum. Abdomen densely and deeply punctate; similar as on pronotum; dorsally punctures without setae; laterally and ventrally with short yellow setae; surface without microsculpture; polished and shiny.

Aedeagus elongate; apical lobe smoothly rounded ending in acute apex; paramera long and sinuate; longer than apical lobe; endophallus with long and straight basal part and short spiral part at apex.

Diagnosis: The species can be easily identified by the absence of eyes. All other species in the genus have at least few omatidia. The overall habitus resembles that of $P$. panamae, but P. panamae has at least 5 omatidia and the pronotum is more densely punctate.

\section{Holotrochopsis FAGEL, 1955}

Holotrochopsis adisi (IRMLER, 2013) comb. nov.

Holotrochus adisi IRMLER, 2013: 160

Distribution: Brazil, Amazonas, Manaus, Ilha Marchanteria, 02.05.1981, 14.09.1981, 02.12.1981, Dec. 1981, 16.02.1982, 18.02.1982, leg. J. Adis (INPA, UIC).

Holotrochopsis amazonicus (IRMLER, 1981) comb. nov.

Holotrochus amazonicus IRMLER, 1981: 395

Distribution: Brazil, Amazonas, Manaus, 01.09.1971, 24.09.1971, leg. U. Irmler (INPA, UIC).

Holotrochopsis danoffburgi (IRMLER, 2001) comb. nov.

Holotrochus danoffburgi IRMLER, 2001: 356

Distribution: Peru, Loreto, Iquitos, 05.05.1992, leg. Danoff-Burg (KNHM); Bolivia, Cochabamba, Valle del Sajita, Estac. Biol., 07.02.1999, leg. R. Anderson (KNHM).

\section{Holotrochopsis pubescens (SHARP, 1876) comb. nov.}

Holotrochus pubescens SHARP, 1876:

Distribution: Brazil, Amazonas, Manaus, Lago Janauarí, 17.01.1972, leg. U. Irmler (UIC); Pará, Tapajos (BMNH); Jacaréacanga, leg. R. Barbosa (AMNH); Tocantins, Nossa Sinhora de Livramento, Pirizal, 15.02.2001, leg. L. Bafttirola (UFMT); Mato Grosso, Poconé, 23.02.2000, leg. N. Pinho (UMFT); 40 km S. Poconé, 15.03.2013, leg. U. Irmler (UIC); Peru, Loreto, Iquitos, 06.05.1992, leg. Danoff-Burg (KNHM); Huánuco, Pucallpa, Panguana, 
Key to the species of Holotrochopsis

Citation of figures refers to IRMLER (2013)

1. Small species, not longer than $2.5 \mathrm{~mm}$.

- Larger species, at least $3.0 \mathrm{~mm}$

2. Punctation of fore-body sparse and fine, interstices between punctures wider than diameter of punctures H. subtilis (SHARP, 1876)

- Punctation of fore-body coarse and dense, interstices between punctures much smaller than diameter of punctures. H. danoffburgi (IRMLER, 2001)

3. Pronotum widest close to the posterior angles (Fig. 17C); evenly narrowed to smoothly rounded anterior angles, antennomeres 6 and 7 more or less quadrate (Fig. 5B) H. siolii (IRMLER, 2000)

Pronotum widest close to the middle; sides evenly narrowed to obtuse or rectangular posterior and obtuse anterior angles, antennomeres 6 and 7 either quadrate or wider than long

4. Antennomeres 6 an 7 wider than long (Fig. 4B), pronotum evenly narrowed to posterior angles, posterior angles obtuse (Fig. 17A) H. pubescens (SHARP, 1876)

Antennomeres 6 and 7 quadrate, pronotum with short emargination in front of posterior angles, posterior angles rectangular

5. Smaller species, $3.3 \mathrm{~mm}$ long, elytra quadrate (Fig. 17D) H. adisi (IRMLER, 2013)

Larger species, $3.7 \mathrm{~mm}$ long, elytra 1.2 times wider than long (Fig. 17B) H. amazonicus (IRMLER, 1981)

01.11.1976, leg. W. Hanagarth (UIC); Guyana, Annai, 08.06.2001, leg. R. Brooks (KNHM).

\section{Holotrochopsis setifera (IRMLER, 2010a) comb. nov.}

Holotrochus setifera IRMLER, 2010: 52

Distribution: Bolivia, Beni, Island Flores, Rio Itenez, 07.08.1964, leg. J.K. Bouseman (AMNH, UIC); Peru, Huánuco, Panguana, Rio Lullapichis, 01.12.2008, leg. F. Wachtel; 23.10.2008, leg. G. Diesel (UIC, VAC).

\section{Holotrochopsis siolii (IRMLER, 2001) comb. nov.}

Holotrochus siolii IRMLER, 2001: 356

Distribution: Brazil, Pará, Rio Xingu, Aluau, (INPA, UIC).

\section{Holotrochopsis subtilis (SHARP, 1876) comb. nov.}

Holotrochus subtilis SHARP, 1876: 391

Distribution: Brazil, Amazonas, Tefé (BMNH); Manaus, Rio Tarumã Mirím, 01.09.1971, Lago Janauarí, 01.02.1972, leg. U. Irmler (UIC); INPA/Smithsonian Res., Terra Firms forest, March 1994, leg. R. Didham (BMNH); Pará, Rio Xingu, Aluau (UIC); Jaceréacanga, Jan. 1970, leg. R. Barbosa (AMNH, UIC).

\section{Discussion}

The tribe Osoriini has a world-wide distribution. According to Herman (2001) 67 genera were differentiated. Together with the two new genera and Antillosorius IrmLer, 2010b a total of 70 genera are known. The Ethiopian region contributes with 26 genera to the total and seems to be the richest fauna regarding genera. Moreover, 16 genera (61\%) are known only from the Ethiopian region. However, the new placement of Neotropical species to the genera Holotrochopsis FAgel, 1955 and Tumboecus FAgel, 1959 shows that some genera might be more widely distributed. Only few genera are known from the Australian (6) and Oceanic (1) regions. With 19 genera, the Neotropical fauna accounts for slightly less genera than the Ethiopian fauna. Among the Neotropical fauna 9 genera (47\%) are restricted to the Neotropics. The endemism rate of genera might be similarly high as in the Ethiopian region, because the genus Osorius seems to be also restricted to the Neotropics. Furthermore, Mimogonia seems to be also restricted to the Neotropics, because the only record from the Palearctic region refers to a female that might be imported to Portugal and not from an autochthonous population in southern Europe. Nevertheless, the Neotropical fauna seems to be mostly related to the Ethiopian fauna, because five genera have been recorded from both regions. A sixth genus can be added, because Neosorius is now recorded from the Neotropics, the Ethiopian region and Madagascar. The new placement of several species to the genus Paratorchus that were formerly described under the genus Holotrochus shows also a relation to the Australian 
region. Two of the Neotropical genera are pantropically distributed, i.e. Holotrochus ErICHSON, 1839 and Mimogonus Fauvel, 1903.

The majority of the Osoriinae species are found in dead and decomposing wood or with leaf litter such as the species of Osorius, Osoriellus, Holotrochus and all have well developed eyes. Many of them might live in the canopy of the rain forest, presumably in differently thick dead branches or twigs. However a large number of genera have soil dwelling species, which can be derived from the reduced or even absent eyes. In the Neotropical region, reduced or absent eyes occur in the genera Paratorchus, Mimotrochus, Neorhabdopsis, Tavakilianidia, and Ouloglene. Thus, approximately $26 \%$ of the genera can be counted to the euedaphic soil fauna.

Several genera might be older than 30-35 mill. years without changing their outer characters. IRMLER (2003) found a species in the Dominican amber that certainly belongs to the genus Oryssoma and might be closely related to Oryssoma politum. Moreover, other species from the Dominican amber resemble Osoriellus.

\section{Acknowledgements}

I heartily thank the curators of museums for their helpful support: L. Herman (AMNH), R. Booth (BMNH), J. Ashe and Z. Falin (KNHM), and M. Fikáček (NMPC). Thanks are also due to Tim Struyve for the delivery of his extensive material from French Guyana, J. Orousset and A. Taghavian (MNHP) for the loan of the type material of Tavakilianidia.

\section{References}

Bernhauer, M. 1905: Neue exotische Staphyliniden. Deutsche Entomologische Zeitschrift 1905: 9-21.

Bernhauer, M. 1908: Beitrag zur Staphylinidenfauna von Südamerika. - Archiv für Naturgeschichte 74: 283-372.

Bernhauer, M. \& Schubert, K. 1910: Coleopterorum Catalogus. Staphylinidae. - Junk, Berlin, p. 988.

BlaCKWElder, R. E. 1943: Monograph of the West Indian beetles of the family Staphylinidae. - Smithsonian United States National Museum Bulletin 182: 1-658.

ERICHSON, G. F. 1839: Genera et species Staphylinorum Insectorum Coleopterorum familiae. - Morin, Berlin, p. 954.

FAgEL, G. 1955: Osoriinae. - Exploration du Parc National de l'Upemba. - Mission G.F. de Wette 39: 1-184.

Fagel, G. 1959: Osoriinae (Coleoptera Polyphaga) Fam. Staphylinidae. Exploration du Parc National de la Garamba. - Mission H. De Saeger 12: 1-205.

Fauvel, A. 1903: Mission de M. Maurice Maindron dans l'Inde méridionale. - Revue d'Entomologie, Caen 22: 149-163.
Hadley, A. 2006: CombineZ 5.3. Public Domain Software (www.hadleyweb.pwp.blueyonder.co.uk).

Herman, L. 2001: Catalog of the Staphylinidae (Insecta: Coleoptera) 1758 to the end of the second millennium. III. Oxytelinae group. - Bulletin of the American Museum of Natural History 265: 1067-1806.

IRMLER, U. 1981: Description of new neotropical Holotrochus and a key to the species of the genus (Coleoptera: Staphylinidae). - The Coleopterists Bulletin 35: 379-397.

IRMLER, U. 1987: New neotropical species of the genus Holotrochus and the new genus Mimotrochus (Coleoptera, Staphylinidae). - Entomologische Arbeiten Museum Frey 35: 81-109.

Irmler, U. 2001: New Neotropical species of the genus Clavilispinus, Aneucamptus, Thoracophorus, and Holotrochus (Coleoptera: Staphylinidae, Osoriinae). Amazoniana 16: 349-361.

IRMLER, U. 2003: Osoriinae (Coleoptera:Staphylinidae) from Dominican amber. - Stuttgarter Beiträge zur Naturkunde Serie B (Geologie und Paläontologie) 342: 1-16.

IRMLER, U. 2005: New Neotropical species of the genus Holotrochus (Coleoptera: Staphylinidae: Osorinae). - Scientific Papers Natural History Museum The University of Kansas 36: 1-18.

IRMLER, U. 2007: The Holotrochus syntheticus group in the Neotropical region - new species, key and geographical distribution (Coleoptera: Staphylinidae: Osoriinae). - Koleopterologische Rundschau 77: 133-142.

IRMLER, U. 2010a: New Neotropical species of Holotrochus ERICHSON, 1939 with special reference to the H. simplex-group (Coleoptera: Staphylinidae: Osoriinae). - Koleopterologische Rundschau 80: 43-62.

IRMLER, U. 2010b: The Neotropical species of the genus Osorius GuÉRIN-Meneville, 1829 with remarks to the Neotropical Osoriini complex. - Beiträge zur Entomologie 60 (2): 363-426.

Irmler, U. 2013: New species of the genus Mimogonia and Holotrochus from South America (Coleoptera: Staphylinidae: Osoriinae). - Acta Entomologica Musei Nationalis Pragae 53: 155-176.

IrMLER, U. 2014a: Additions to the Neotropical species of the genus Osorius GuÉRIN-MÉneville, 1929 (Coleoptera: Staphylinidae: Osoriinae). - Koleopterologische Rundschau 84: 101-113.

IRMLER, U. 2014b: The Neotropical species of the genus Osoriellus FAGEL, 1959 (Coleoptera: Staphylinidae: Osoriinae). - Contributions to Entomology, Beiträge zur Entomologie 64 (2): 231-354.

McColl, H. P. 1982: Osoriinae (Insecta: Coleoptera: Staphylinidae). - Fauna of New Zealand 2: 1-89. 
McColl, H. P. 1985: Nototorchus nom. nov. and Paratorchus nom. nov., replacement names for Nototrochus McColl, 1982 and Paratrochus McColl, 1982 (Coleoptera: Staphylinidae: Osoriinae). - New Zealand Journal of Zoology 11: 355-356.

Notman, H. 1925: A synoptic review of the beetles of the tribe Osoriini from the Western Hemisphere. Proceedings of the US National Museum 67: 1-26.
Orousset, J. 1985: Deux Osoriinae anophtalmes de Guyane Française. - Revue française Entomologique (N.S.) 7: 60-66.

Sharp, D. 1876: Contributions to the Staphylinidae of the Amazon valley. - Transactions of the Royal entomological Society of London 1876: 27-424.
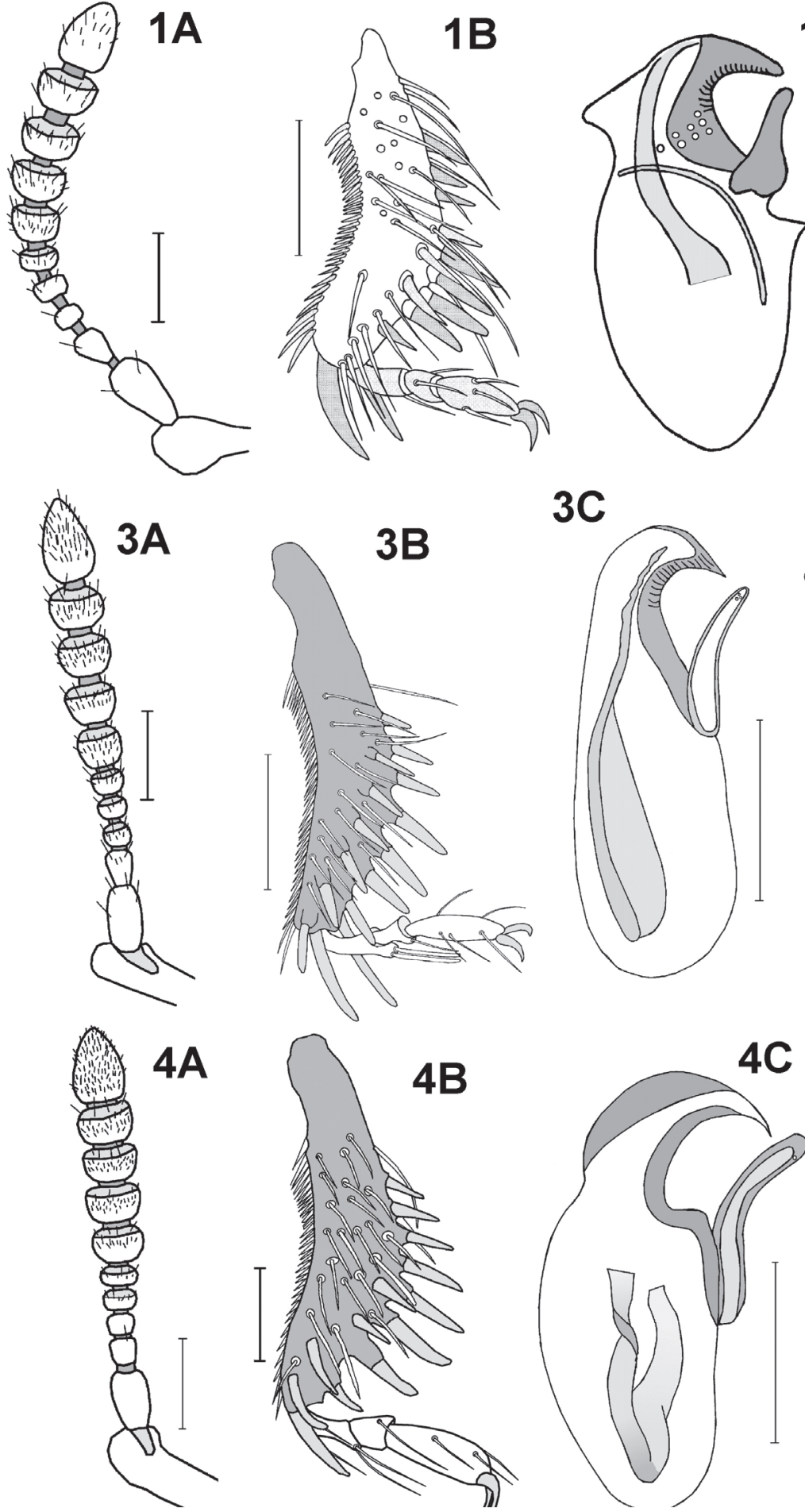

$3 \mathrm{C}$
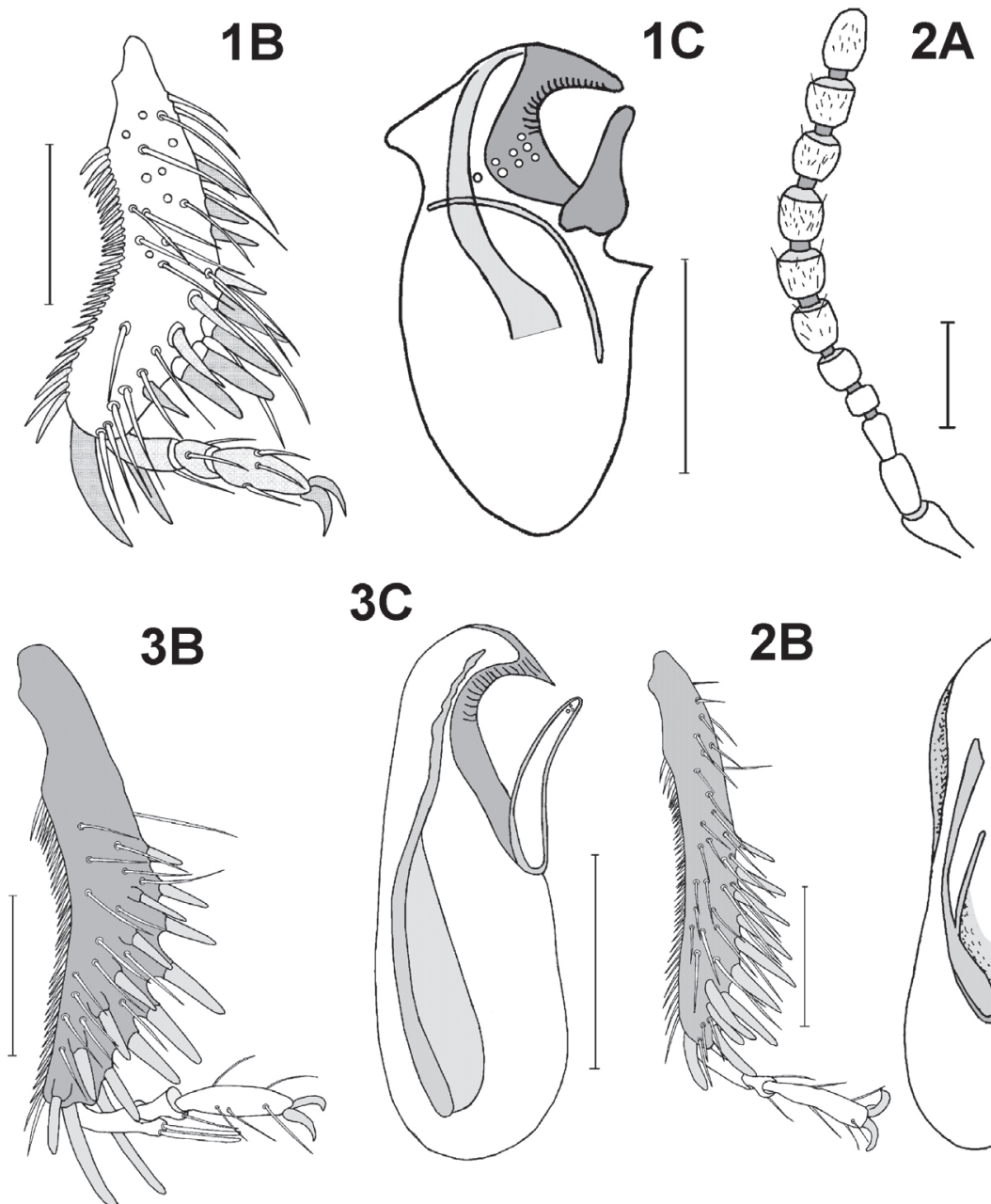

$2 \mathrm{~A}$

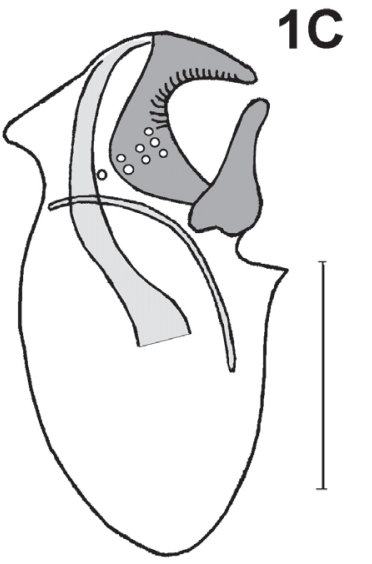

2C

Fig. 1-4: Ouloglene barberi (1), Oryssoma schwarzi (2), O. exalatum (3), O. politum (4); antenna (A), protibia in posterior aspect (B), aedeagus (C), last sternite (D); scale bar: $0.1 \mathrm{~mm}$. 

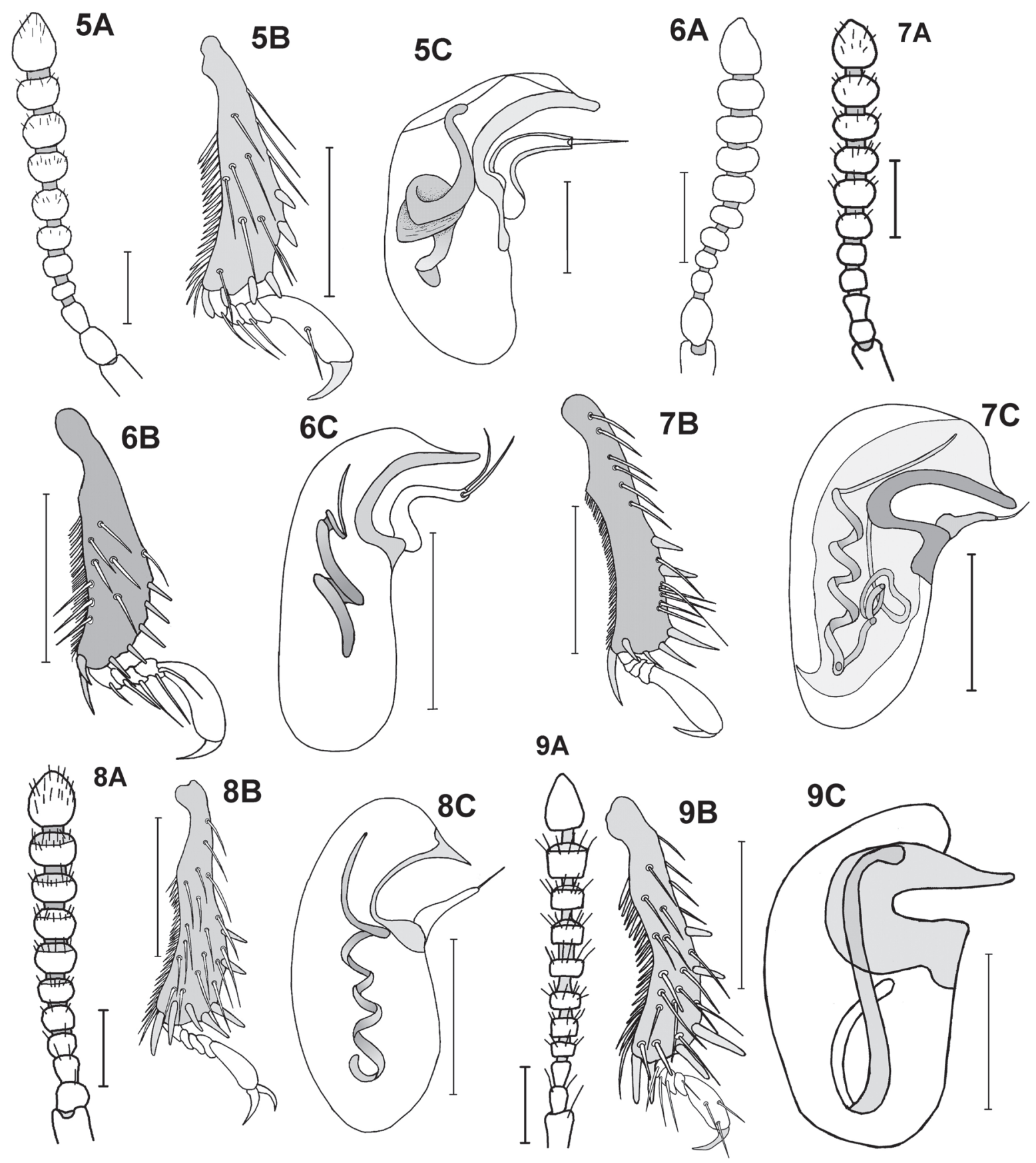

Fig. 5-9: Neorhapdopsis brasiliensis (5), N. pecki (6), N. lutzi (7), N. panamae (8), Tumboecus verhaaghi (9), antenna (A), protibia in posterior aspect (B), aedeagus (C); scale bar: $0.1 \mathrm{~mm}$. 

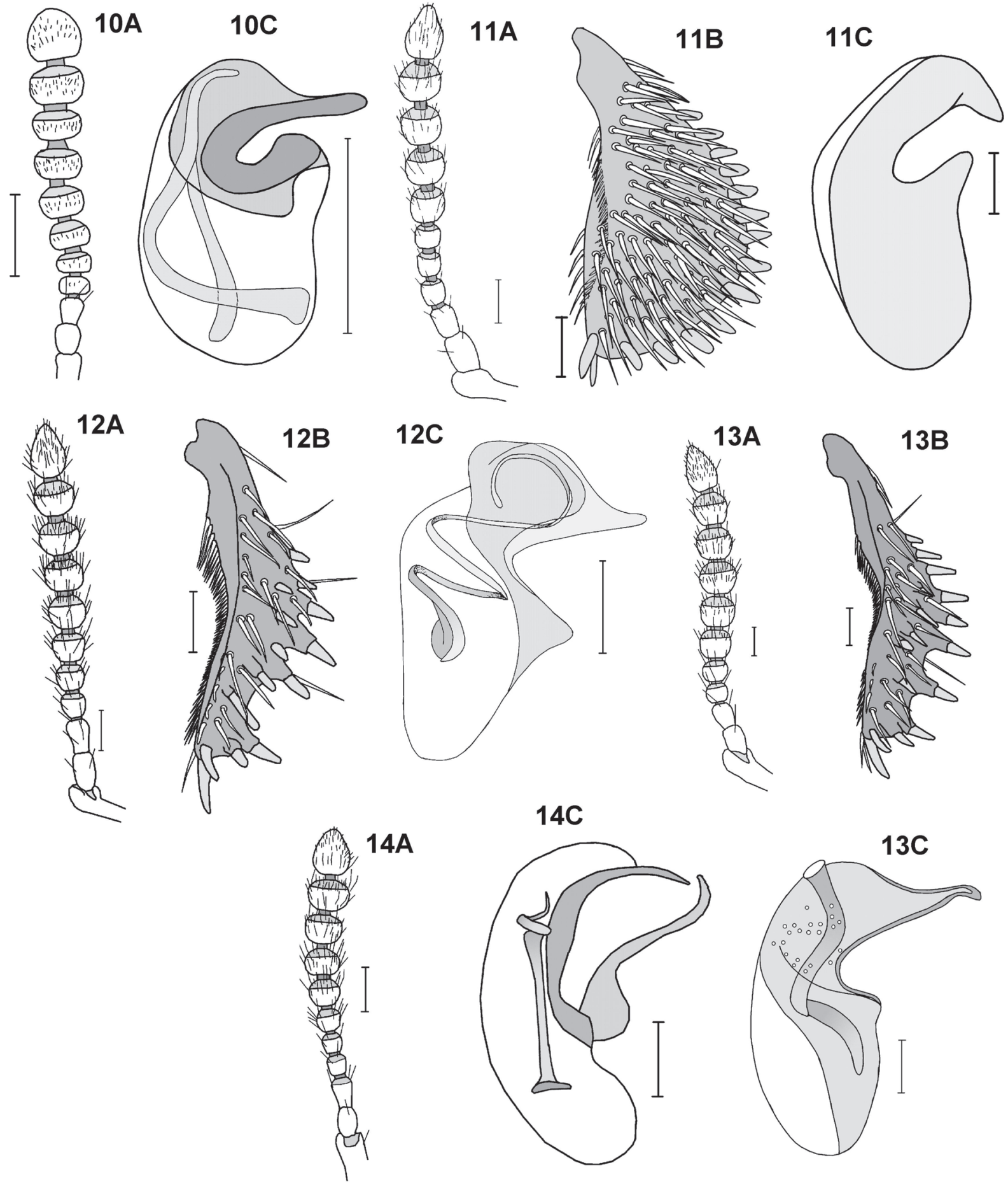

Fig. 10-14: Tumboecus struyvei (10); Osoriosetus hanagarthi (11), Neosorius brasiliensis (12), N. mexicanus (13), Paratrochus tilli (14); antenna (A), protibia in posterior aspect (B), aedeagus (C); antenna (A), protibia in posterior aspect (B), aedeagus (C); scale bar: $0.1 \mathrm{~mm}$. 

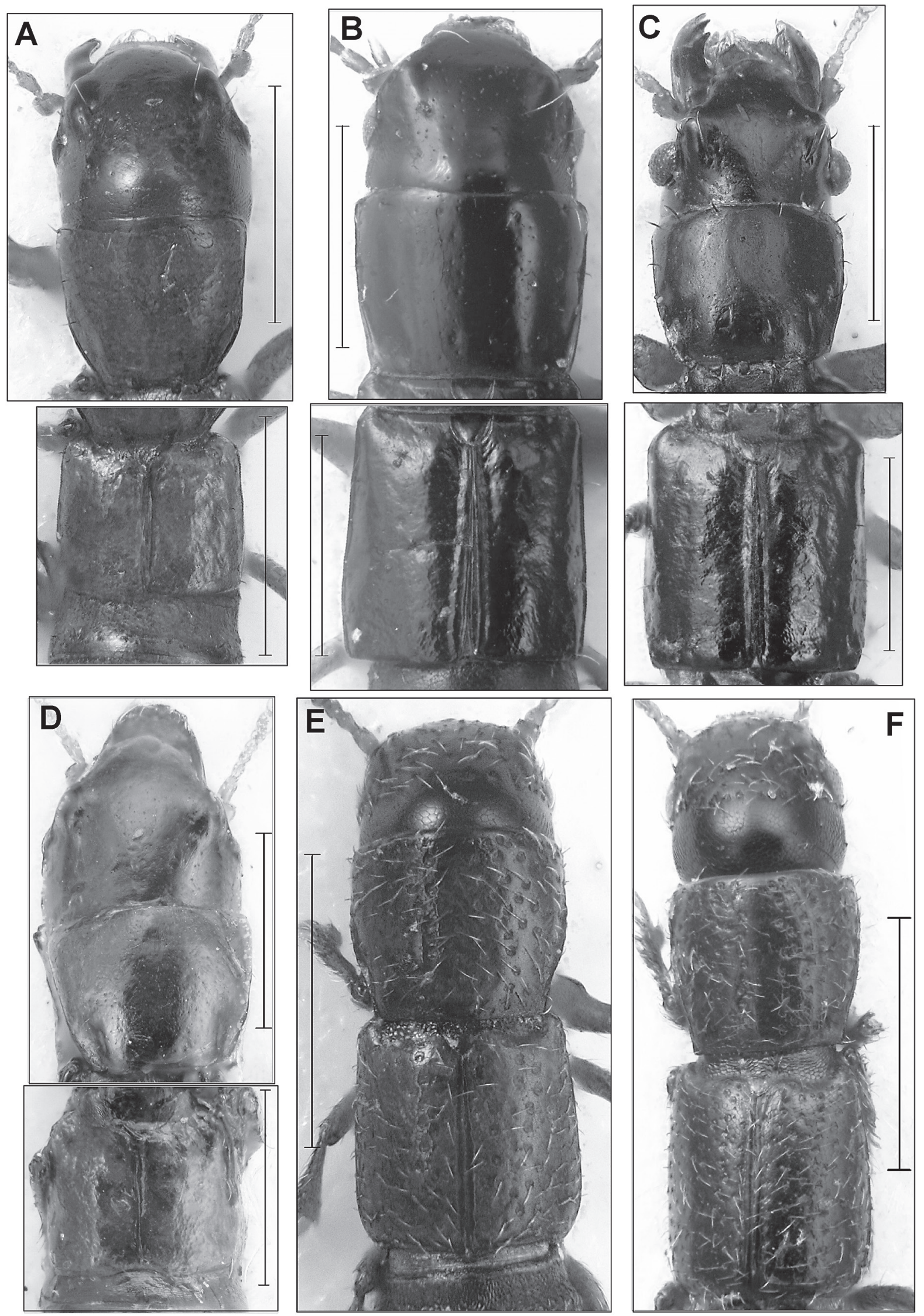

Fig. 15: Head, pronotum, and elytra of Ouloglene barberi (A), Oryssma schwarzi (B), O. politum (C), O. exalatum (D), Tumboecus verhaaghi (E), and T. struyvei (F); scale bar: $0.5 \mathrm{~mm}$. 

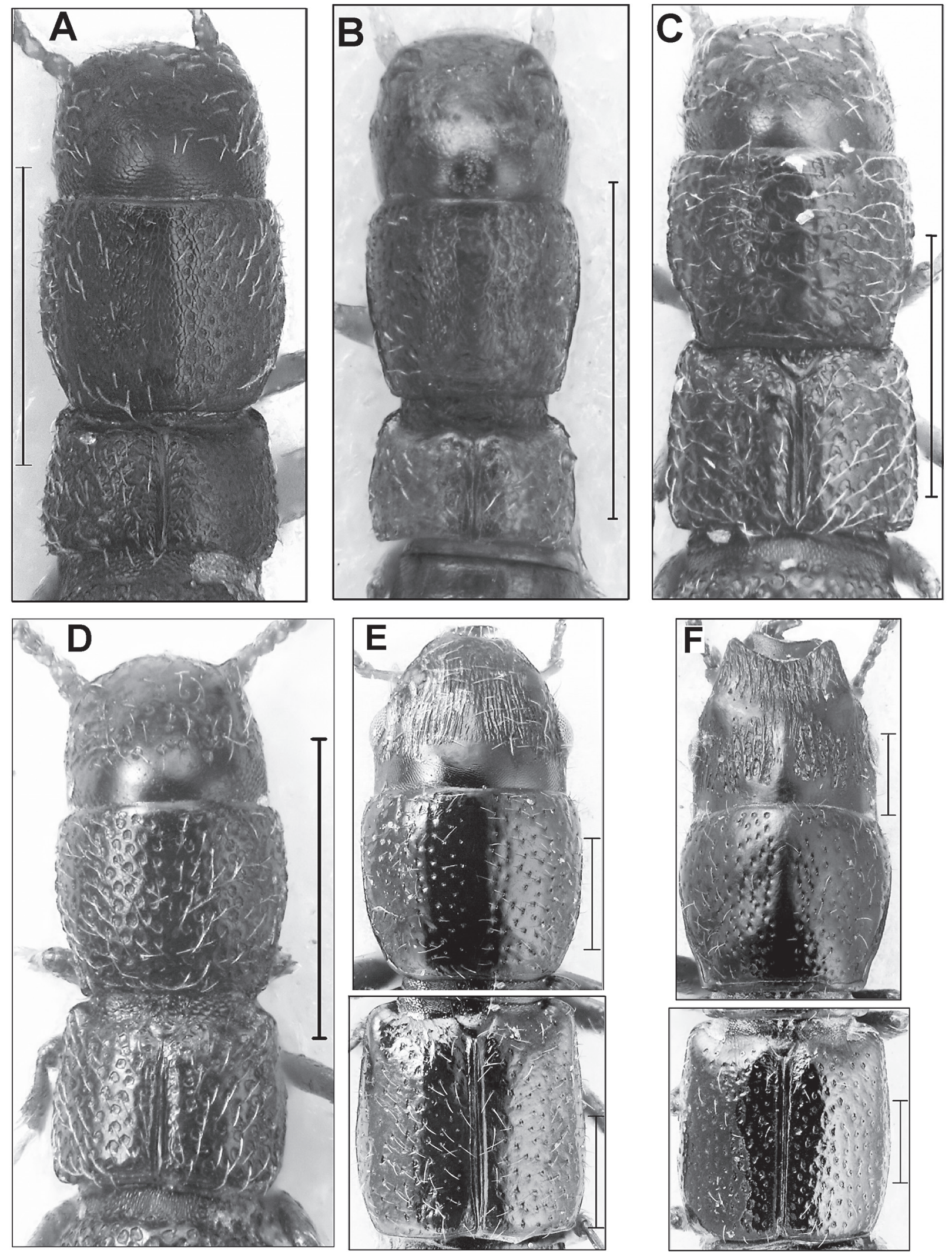

Fig. 16: Head, pronotum, and elytra of Neorhabdopsis brasiliensis (A), N.pecki (B), N. lutzi (C), N. panamae (D), Neosorius brasiliensis $(\mathrm{E})$, and N. mexicanus $(\mathrm{F})$; scale bar: $0.5 \mathrm{~mm}$. 

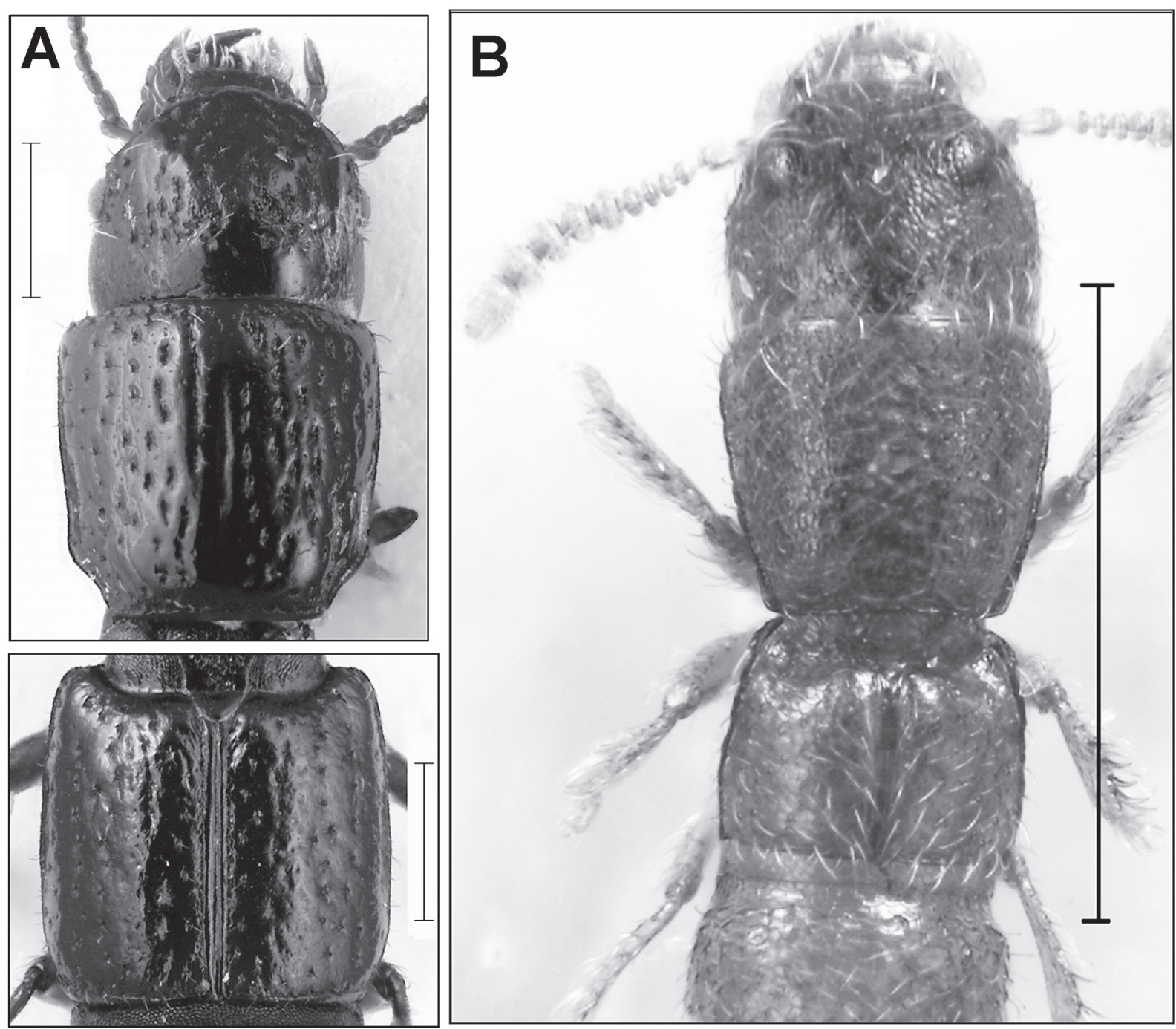

Fig. 17: Head, pronotum, and elytra of Osoriosetus hanagarthi (A) and Tavakilianidia anophtalma (B); scale bar: $0.5 \mathrm{~mm}$. 

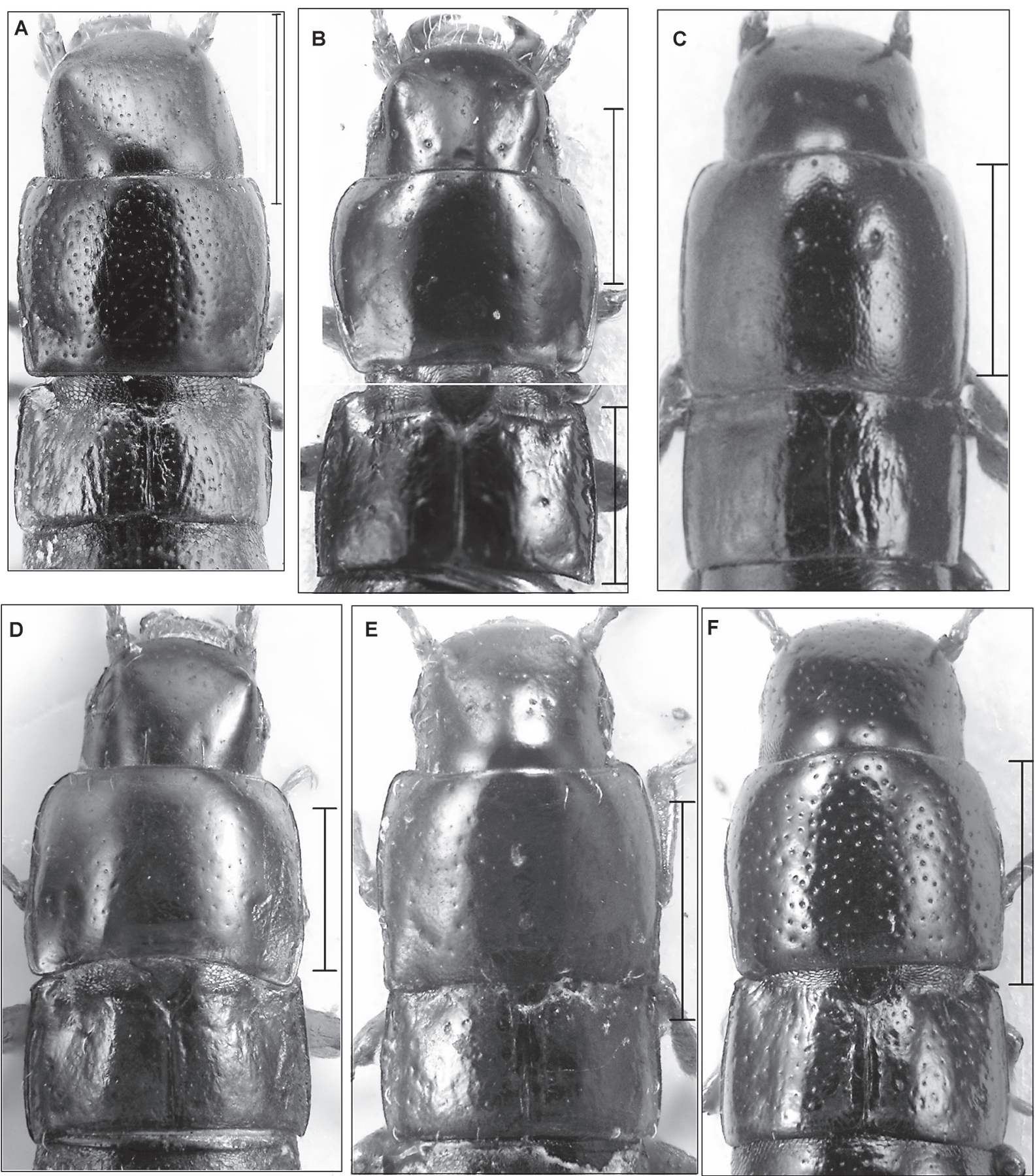

Fig. 18: Head, pronotum, and elytra of Paratrochus tilli (A), P. brasiliensis (B), P. chilensis (C), P. columbiensis (D), P. panamae (E), and $P$. chiriquensis (F); scale bar: $0.5 \mathrm{~mm}$. 

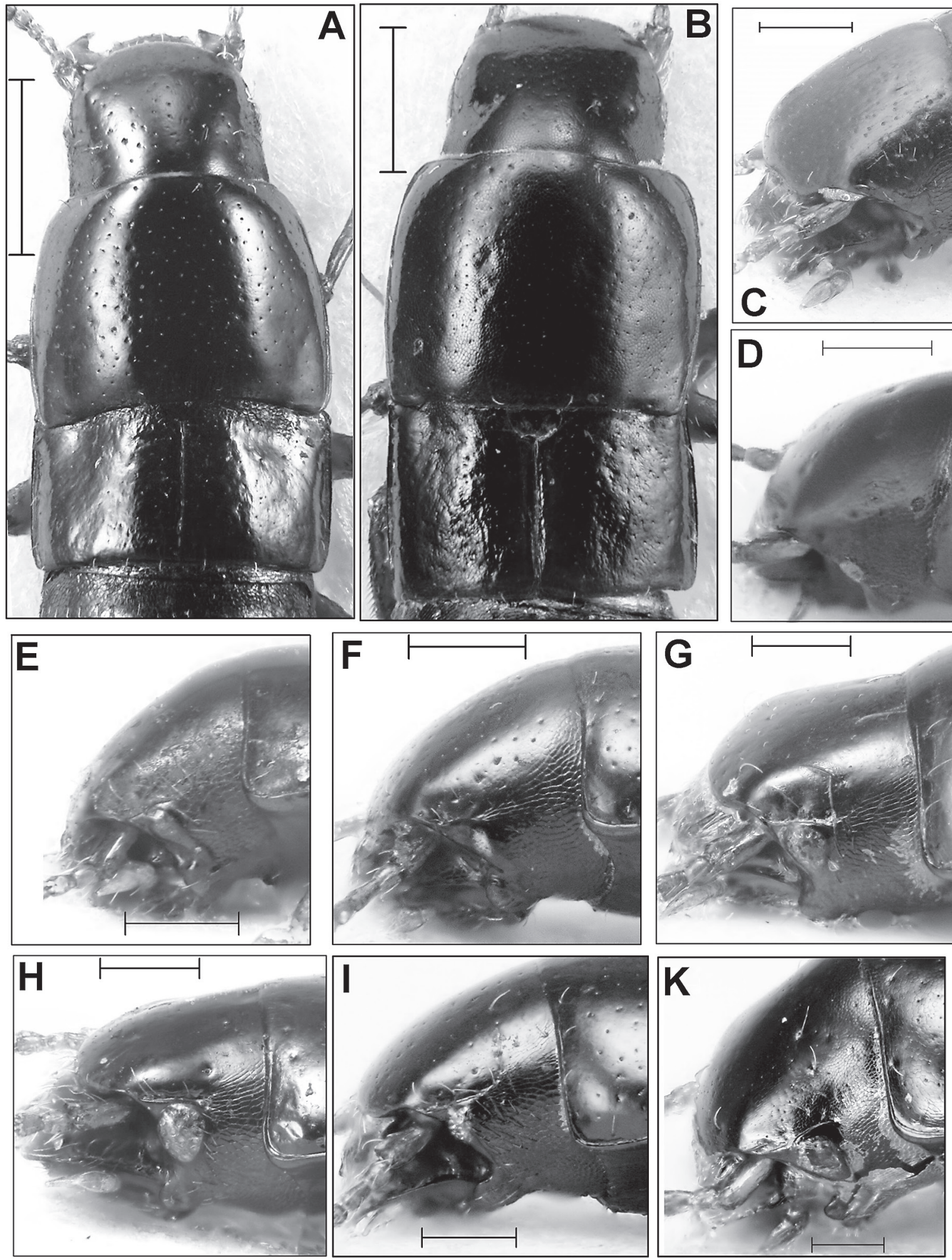

Fig. 19: Head, pronotum, and elytra of Paratrochus bolivianus (A), P. breviatus (B), and head in lateral aspect of P. tilli (C), P. chilensis (D), P. panamae (E), P. chiriquensis (F), P. columbiensis (G), P. brasiliensis (H), P. bolivianus (I), and P. breviatus $(\mathrm{K})$; scale bar of A and B: $0.5 \mathrm{~mm}$; scale bar of C-K: $0.2 \mathrm{~mm}$. 